\title{
Anaplastic oligodendrogliomas with Ip I9q codeletion have a proneural gene expression profile
} François Ducray ${ }^{1}$, Ahmed Idbaih ${ }^{1}$, Aurélien de Reyniès ${ }^{2}$, Ivan Bièche ${ }^{3}$, Joëlle Thillet ${ }^{1}$, Karima Mokhtari ${ }^{1}$, Séverine Lair ${ }^{4}$, Yannick Marie${ }^{1}$, Sophie Paris ${ }^{1}$, Michel Vidaud ${ }^{3}$, Khê Hoang-Xuan¹, Olivier Delattre ${ }^{4}$, JeanYves Delattre ${ }^{1}$ and Marc Sanson*1

Address: ${ }^{1}$ Unité INSERM U711, Université Paris VI, 47-83 Boulevard de l'Hôpital, 75013 Paris, France, 2Programme Cartes d'Identité des Tumeurs (CIT), Ligue Nationale Contre le Cancer, Service de Bioinformatique, 14 rue Corvisart, 75014 Paris, France, ${ }^{3}$ Unité INSERM U745, Faculté des Sciences Pharmaceutiques et Biologiques, Université René Descartes - Paris V, 4 avenue de l'Observatoire 75270 Paris, France and ${ }^{4}$ Unité INSERM U830, Unité de Génétique Somatique et Service de Bio-Informatique, Institut Curie, 26 rue d'Ulm, 75006 Paris, France

Email: François Ducray - francoisducray@yahoo.fr; Ahmed Idbaih - ahmed.idbaih@gmail.com; Aurélien de Reyniès - ReyniesA@liguecancer.net; Ivan Bièche - ivan.bieche@univ-paris5.fr; Joëlle Thillet - thillet@ext.jussieu.fr; Karima Mokhtari - karima.mokhtari@psl.aphp.fr; Séverine Lair - severine.lair@curie.fr; Yannick Marie - yamarie@ccr.jussieu.fr; Sophie Paris - sophie.paris@ccr.jussieu.fr;

Michel Vidaud - michel.vidaud@univ-paris5.fr; Khê Hoang-Xuan - khe.hoang-xuan@psl.aphp.fr; Olivier Delattre - olivier.delattre@curie.fr; Jean-Yves Delattre - jean-yves.delattre@psl.aphp.fr; Marc Sanson* - marc.sanson@psl.aphp.fr

* Corresponding author

\section{Published: 20 May 2008}

Molecular Cancer 2008, 7:4| doi:|0.||86/|476-4598-7-4|
Received: 15 December 2007

Accepted: 20 May 2008

This article is available from: http://www.molecular-cancer.com/content/7/I/4I

(C) 2008 Ducray et al; licensee BioMed Central Ltd.

This is an Open Access article distributed under the terms of the Creative Commons Attribution License (http://creativecommons.org/licenses/by/2.0), which permits unrestricted use, distribution, and reproduction in any medium, provided the original work is properly cited.

\begin{abstract}
Background: In high grade gliomas, Ip I9q codeletion and EGFR amplification are mutually exclusive and predictive of dramatically different outcomes. We performed a microarray gene expression study of four high grade gliomas with Ip I9q codeletion and nine with EGFR amplification, identified by CGH-array.

Results: The two groups of gliomas exhibited very different gene expression profiles and were consistently distinguished by unsupervised clustering analysis. One of the most striking differences was the expression of normal brain genes by oligodendrogliomas with Ip Iqq codeletion. These gliomas harbored a gene expression profile that partially resembled the gene expression of normal brain samples, whereas gliomas with EGFR amplification expressed many genes in common with glioblastoma cancer stem cells. The differences between the two types of gliomas and the expression of neuronal genes in gliomas with Ip I9q codeletion were both validated in an independent series of I6 gliomas using real-time RT-PCR with a set of 22 genes differentiating the two groups of gliomas (AKRIC3, ATOH8, BMP2, C20orf42, CCNBI, CDK2, CHI3LI, CTTNBP2, DCX, EGFR, GALNTI3, GBPI, IGFBP2, IQGAPI, LICAM, NCAMI, NOG, OLIG2, PDPN, PLAT, POSTN, RNFI35). Immunohistochemical study of the most differentially expressed neuronal gene, alpha-internexin, clearly differentiated the two groups of gliomas, with IpI9q codeletion gliomas showing specific staining in tumor cells.

Conclusion: These findings provide evidence for neuronal differentiation in oligodendrogliomas with Ip I9q codeletion and support the hypothesis that the cell of origin for gliomas with IpI $9 \mathrm{q}$ codeletion could be a bi-potential progenitor cell, able to give rise to both neurons and oligodendrocytes.
\end{abstract}




\section{Background}

The $1 \mathrm{p} 19 \mathrm{q}$ codeletion and EGFR amplification are mutually exclusive and related to dramatically different outcomes in high grade gliomas. The $1 \mathrm{p} 19 \mathrm{q}$ codeletion is strongly associated with an oligodendroglial phenotype and favorable prognosis [1]. It has recently been shown to be mediated by a specific $t(1 ; 19)(q 10 ; p 10)$ translocation [2]. To date the efforts performed to identify the genes specifically involved in the breakpoint have failed, mostly because both $1 p$ and $19 q$ centromeric regions contain highly repeated sequences. As a consequence the molecular mechanisms underlying the particular phenotype and the favorable outcome of this subset of gliomas remain completely unknown. Reliable detection of 1p19q codeletion requires an appropriate technique, such as CGHarray. Indeed, the most widely used LOH studies may not distinguish this signature from partial distal $1 \mathrm{p}$ and $19 \mathrm{q}$ deletion or gain, which have radically different prognostic implications [1]. On the other hand, EGFR amplification is tightly associated with chromosome 10 loss and gain of chromosome 7 , representing another characteristic genomic signature [3]. EGFR amplification is more frequent in glioblastomas, but it is also found in a subset of anaplastic oligodendrogliomas and, in this setting, is predictive of extremely poor prognosis [4]. Recently, malignant gliomas have been separated into three expression profiles with distinct outcomes and histological correlations: 1) the proneural profile with a better prognosis, mostly corresponding to anaplastic gliomas (oligodendrogliomas and astrocytomas); 2) the proliferative and 3) mesenchymal profiles, corresponding mainly to glioblastomas [5]. However, correlation with $1 \mathrm{p} 19 \mathrm{q}$ codeletion is still missing. Based on a set of gliomas analyzed by CGHarray [3], we selected tumors displaying one of these two characteristics and mutually exclusive patterns $-1 \mathrm{p} 19 \mathrm{q}$ codeletion or EGFR amplification- and compared their gene expression profiles.

\section{Methods \\ Samples}

The microarray study was done on 13 gliomas selected from the Salpêtrière database, based on the following criteria: 1) CGH-array profile showing either whole 1p19q codeletion or EGFR amplification, 2) high quality RNA availability. The samples were provided as snap-frozen sections of areas immediately adjacent to the region used for the histopathological diagnosis according to the World Health Organization Classification (WHO 2000). This set included 4 grade III oligodendrogliomas with complete $1 \mathrm{p} 19 \mathrm{q}$ codeletion and 9 gliomas with EGFR amplification (5 glioblastomas (GBM), 3 grade III oligodendrogliomas, 1 grade III oligoastrocytoma (OAIII)). Genomic characterization was performed using CGH array as previously described [1]. Among the 9 tumors with EGFR amplification, 8 out of 9 had chromosome $10 \mathrm{q}$ loss and chromosome 7 gain; 4 had a gain of chromosome $1 \mathrm{p}$, and 4 had a partial loss of chromosome $1 \mathrm{p}$. Among the 4 tumors with complete $1 \mathrm{p} 19 \mathrm{q}$ codeletion none had EGFR amplification, 10q loss or chromosome 7 gain, and 2 had complete chromosome 4 loss. In order to compare the gene expression profile of the gliomas with normal brain, we used the gene expression data of 5 samples of corpus callosum (GSM175855, GSM175856, GSM175857, GSM175858, GSM176050) and 5 samples of cortex (GSM176049, GSM176344, GSM176345, GSM176346, GSM176347), available in the Gene Expression Omnibus repository (GSE7307) [6]. To compare the gene expression profile with glioblastomas cancer stem cells (CSC), we used the data of Beier et al. (GSE7181) [7]. All raw and normalized data files for the microarray analysis have been deposited [8] at the European Bioinformatics Institute (Hinxton, UK), and are publicy available under accession number E-MEXP-1507.

\section{RNA extraction and hybridization}

Approximately $50 \mathrm{mg}$ of tissue from each tumor were used for total RNA extraction using the RNeasy Lipid Tissue mini kit (Qiagen, CA), according to the manufacturer instructions. RNA quality was verified with the Bioanalyser System (Agilent Technologies, Paolo Alto, CA), using the RNA Nano Chips. One and half micrograms of RNA were processed for hybridization on the Genechip Human Genome U133 Plus 2.0 Expression array (Affymetrix, CA), which contains over 54.000 probe sets analyzing the expression level of over 47,000 transcripts and variants, including 38.500 well-characterized human genes. The processing was done according to the recommendations of the manufacturer.

\section{Data analysis}

Except as indicated, all transcriptome analysis was carried out using either R-system software (version 2.4.1) packages including those of Bioconductor [9] or original $\mathrm{R}$ code (A. de R.). Normalization was performed using the RMA method [10]. Clustering analysis was performed as previously reported [11]. Class comparison using a univariate t-test was performed using BRB Array Tools developed by Dr. Richard Simon and Amy Peng Lam [12]. A pvalue $<0.001$ was used to define differentially expressed genes. Gene set enrichment analysis was performed using GSEA v2.0 software [13] as described by Subramanian et al. [14]. For enrichment analysis in specific gene ontology terms (GO terms), we used a hypergeometric test to measure the association between a gene (probe set) list and a GO term. To this end, we mapped both the gene list and GO term related proteins to non-redundant Entrez Gene identifiers. The mapping of a probe set list to Entrez Gene ids was done using the annotation file $\mathrm{HG}$ U133_Plus_2.annot.csv [15]. For each GO term, we obtained the list of non-redundant related protein identi- 
fiers - either directly associated with the GO term or with one of its descendants - and mapped it to a non-redundant list of Entrez Gene ids. GO terms and their relationships (parent/child) were downloaded from The Gene Ontology site [16]. The list of proteins associated with GO terms (table gene_association.goa_human) was downloaded from [17]. We designated a threshold significance level for the hypergeometric test of $\mathrm{p}<0.01$ and the criteria that a GO term was represented by at least 2 Entrez Gene identifiers. Enrichment analysis of genes located on specific chromosomes was performed using DAVID tools [18].

\section{Real-time RT-PCR}

Quantitative RT-PCR was performed as previously described [19]. TBP (Genbank accession no. NM 003194), which encodes the TATA box-binding protein (a component of the DNA-binding protein complex transcription factor II D), was selected as an endogenous control because the levels of its transcript did not change across various normal tissues and tumor samples. The expression of the following 22 genes was quantified: AKR1C3 (upper primer (UP) 5'-CGT ATT TCA ACC GGA GTA AAT TGC TA-3', lower primer (LP) 5'-GTT CGG GTC CAC CCA TCG T-3'); ATOH8 (UP 5'-CAC ACC ATC AGC GCA GCC TT-3', LP 5'-GAT GGC CAG TTT GGA CAG CTT CT-3'); BMP2 (UP 5'-CGC AGC TTC CAC CAT GAA GAA TC-3', LP 5'-GAA TCT CCG GGT TGT TTT CCC ACT-3'); C20orf42 (UP 5'-AAG GAA CTT GAA CAA GGA GAA CCA CT-3', LP 5'-GGC ACA ACT TCG CAG CCT CTA-3'); CCNB1 (UP 5'-TGG ATA ATG GTG AAT GGA CAC CAA3', LP 5'-GCC AGG TGC TGC ATA ACT GGA-3'); CDK2 (UP 5'-GGA CGG AGC TTG TTA TCG CAA AT-3', LP 5'CCT TGG CCG AAA TCC GCT T-3'); CHI3L1 (UP 5'-GAC CAC AGG CCA TCA CAG TCC-3', LP 5'-TGT ACC CCA CAG CAT AGT CAG TGT T-3'); CTTNBP2 (UP 5'-CCC TCT CCA TCC TTG AAG CAG T-3', LP 5'-GAA GCT TCT CCA TTT CCA GCT TCT-3'); DCX (UP 5'-AGC CAA GAG CCC TGG TCC TAT-3', LP 5'-TGG AGG TTC CGT TTG CTG AGT-3');EGFR (UP 5'-GGA GAA CTG CCA GAA ACT GAC C-3', LP 5'-GCC TGC AGC ACA CTG GTT G-3');GALNT13 (UP 5'-GTG GCC TAT TTT CTA TTG ACA GAA ACT-3', LP 5'-CCT CCA CAT TGC CAA ATC CTA A-3');GBP1 (UP 5'CCT CGC TCT TAA ACT TCA GGA ACA-3', LP 5'-CCT TTC GTC GTC TCA TTT TCG T-3');IGFBP2 (UP 5'-GGC CCT CTG GAG CAC CTC TAC T-3', LP 5'-CCG TTC AGA GAC ATC TTG CAC TGT-3');IQGAP1 (UP 5'-AGA ACA GAC CAG ATA CAA GGC GA-3', LP 5'-CTT AGG CAA TCC AAT CTC ATC CA-3');L1CAM (UP 5'-CTG GTT GTC TTC CCC ACA GAT GA-3', LP 5'-TCG TCC AGC GGA ACT GCA CT3');NCAM1 (UP 5'-CCA CAG CCA TCC CAG CCA A-3', LP 5'-GAC GAT GAG GAT GCC CAC GAT-3');NOG (UP 5'AAG AAG CAG CGC CTA AGC AAG A-3', LP 5'-GTC GTT CCA CGC GTA CAG CA-3');OLIG2 (UP 5'-CGC CAG AGC CCG ATG ACC TT-3', LP 5'-GAC ACG GTG CCC CCA
GTG AA-3');PDPN (UP 5'-GTG ACT CCA GGA ACC AGC GAA-3', LP 5'-TGA CAC TTG TTG CCA CCA GAG TT3');PLAT (UP 5'-AGC AGG CCC TGT ACT TCT CAG ATT3', LP 5'-ACG TGG CCC TGG TAT CTA TTT CA-3');POSTN (UP 5'-GTC CTA ATT CCT GAT TCT GCC AAA-3', LP 5'GGG CCA CAA GAT CCG TGA A-3');RNF135 (UP 5'-TGC CTG ACC AGA GCC ACC C-3', LP 5'-GAT GGA TGG CCC ACT GAG CA-3'); TBP (UP 5'-TGC ACA GGA GCC AAG AGT GAA-3', LP 5'-CAC ATC ACA GCT CCC CAC CA-3'). RT-PCR validation was done in an independent set of 16 gliomas (8 grade III oligodendrogliomas with complete $1 \mathrm{p} 19 \mathrm{q}$ codeletion and 8 glioblastomas with EGFR amplification) and on 3 samples of normal brain (temporal lobe obtained during surgery for epilepsy).

\section{Immunohistochemistry}

Immunohistochemical analyses were carried out on paraffin sections using antibodies directed against internexin neuronal intermediate filament protein alpha (INA) [20]. Immunostaining was studied in five glioblastomas with EGFR amplification and five anaplastic oligodendrogliomas with complete 1p19q codeletion.

\section{Results \\ Transcriptomic differences partly reflect the underlying genomic alterations}

To study the relationship between the differences in gene expression profile and the underlying genomic alterations, we looked at the genomic localization of the differentially expressed genes. Class comparison using a univariate t-test demonstrated that 4458 probe sets were differentially expressed between the two groups of gliomas with a p-value $<0.001$ and a maximum false discovery rate of $1.2 \%$ (see Additional file 1 ). The set of overexpressed genes in gliomas with EGFR amplification was significantly enriched in genes located on chromosome 1 (305 genes, $\mathrm{p}<10^{-4}$ ), chromosome 19 (151 genes, $\left.\mathrm{p}<10^{-4}\right)$, chromosome 7 (109 genes, $\left.\mathrm{p}<10^{-4}\right)$ and chromosome 4 ( 85 genes, $\mathrm{p}<10^{-4}$ ). In contrast, the set of overexpressed genes in gliomas with $1 \mathrm{p} 19 \mathrm{q}$ codeletion was significantly enriched in genes located on chromosome 10 (216 genes, $\left.\mathrm{p}<10^{-4}\right)$. Thus, gene expression and copy number variation dynamics were tightly correlated in both tumor groups. This was even more obvious when we plotted the differentially expressed probe sets localized on chromosome 1, 19 and 10 according to their genomic localization and the $\log 2$ ratio of their geometric mean in both tumor groups (Figure 1). Indeed, almost all differentially expressed genes localized on $1 p$ and $19 q$ were underexpressed in gliomas with $1 \mathrm{p} 19 \mathrm{q}$ codeletion, whereas differentially expressed genes localized to $1 \mathrm{q}$ and 19p were equally distributed (Figure 1). 


\section{Chromosome 1}

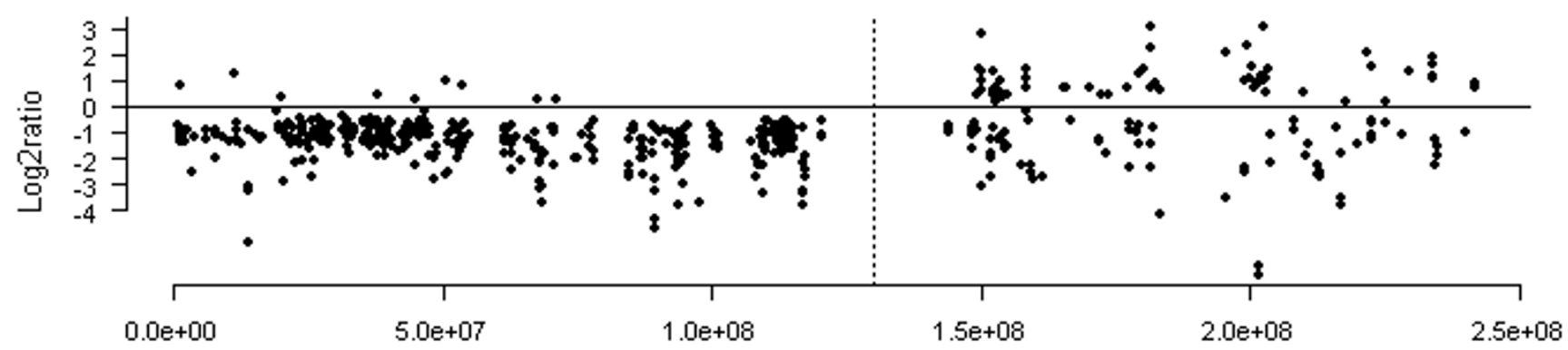

Genomic position

\section{Chromosome 19}

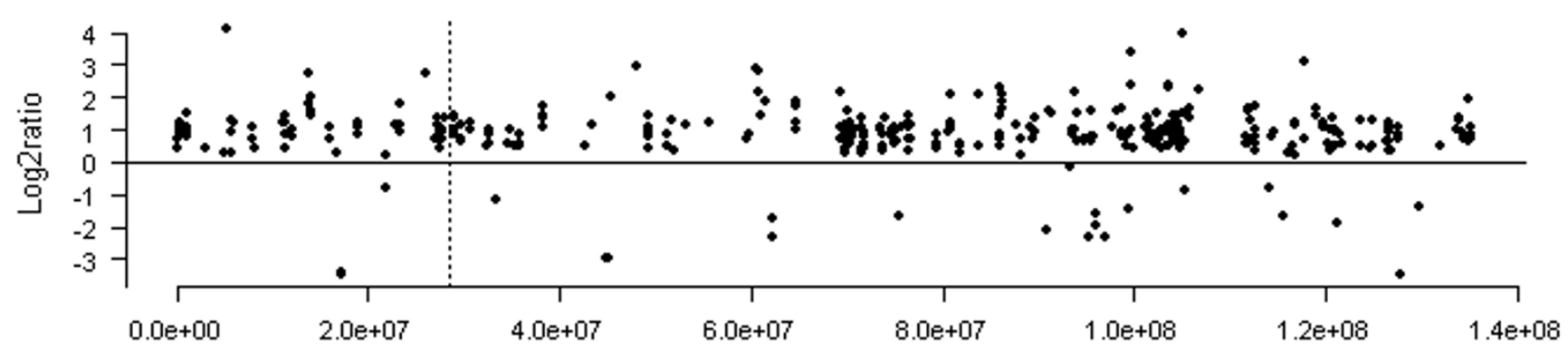

Genomic position

Chromosome 10

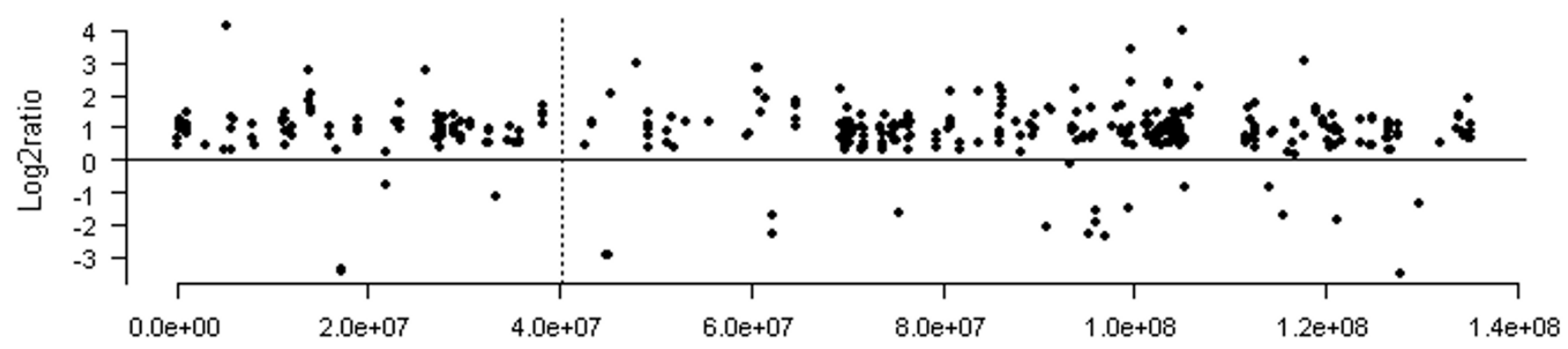

Genomic position

Figure I

Genomic localization of the differentially expressed probe sets $(\mathrm{p}<0.00 \mathrm{I})$ localized on chromosome I, I9 and 10. Each probe set is represented by a dot. Probe sets are ordered along the $x$ axis according to their genomic position (only probe sets with unambiguous genomic mapping on UCSC were used). For each chromosome, the telomere of the short arm is on the left, and the telomere of the long arm is on the right. The dashed vertical line represents the position of the centromere. The $y$ axis corresponds to the log 2 ratio of the geometric mean in the gliomas with complete Ip $19 q$ loss versus the gliomas with EGFR amplification. Almost all probe sets localized on Ip and $19 q$ were underexpressed in gliomas with I $I 9 q$ codeletion, whereas most of the probe sets localized on chromosome 10 were overexpressed. 


\section{Unsupervised analysis consistently distinguishes the two groups of gliomas}

In order to study the differences in gene expression profile, we performed unsupervised hierarchical clustering analysis of the 13 glioma samples. This analysis was done using the 1366 probe sets whose expression varied the most across samples (this corresponds to the probe sets with a robust coefficient of variation ( $\mathrm{rCV})$ superior to the 97.5 ${ }^{\text {th }} \mathrm{rCV}$ percentile). As shown in Figure 2, gliomas with 1p19q codeletion and gliomas with EGFR amplification segregated into two distinct groups. This clustering was extremely robust and was conserved across different gene
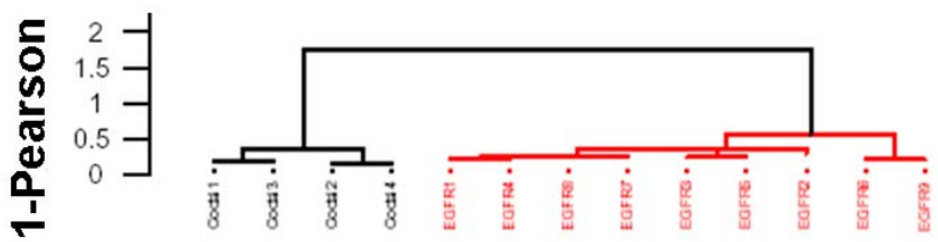

1p19q EGFR 000060G00GG
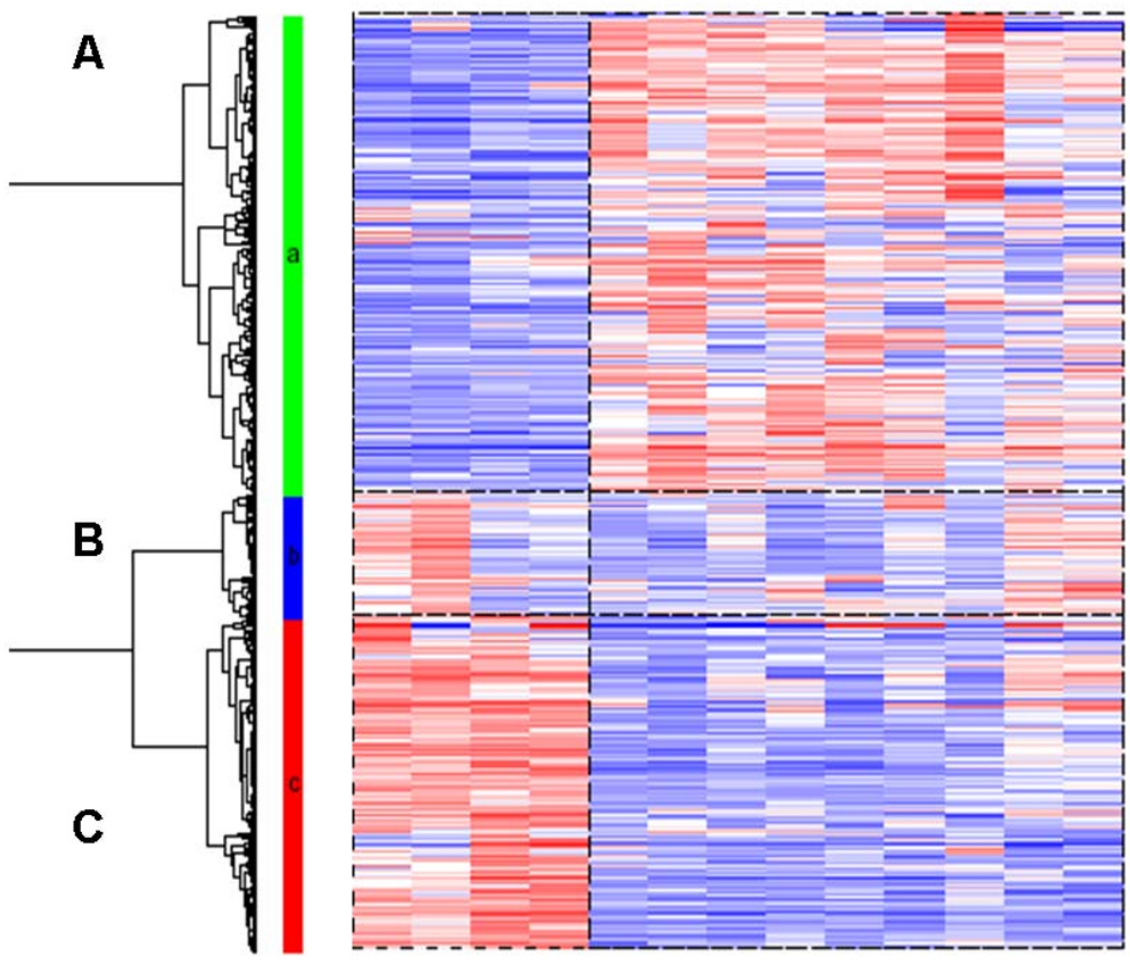

\section{Proliferation}

Extracellular matrix

Immune response

Embryonic development

Angiogenesis

\section{Synaptic transmission}

Neurogenesis

Synaptic transmission

Figure 2

Unsupervised clustering of 4 oligodendrogliomas with Ip I 9q codeletion and 9 gliomas with EGFR amplification. Unsupervised hierarchical clustering was performed using the 1366 probe sets whose expression varied the most across the I 3 samples (probe sets with a robust coefficient of variation superior to the $97.5^{\text {th }}$ percentile). Samples and genes were clustered using Ward's linkage and I-Pearson correlation coefficient. For each probe set, data were median-centered (white), with the lowest and highest intensity values in blue and red, respectively. $I p|9 q=| p \mid 9 q$ codeletion, EGFR $=E G F R$ amplification. The gliomas were classified into 2 groups according to their genomic profile. Gliomas with EGFR amplification were classified into one cluster irrespective of their histology (red = glioblastoma, green = grade III oligodendroglioma, blue = grade III oligoastrocytoma). Gene cluster A was enriched in genes involved in proliferation, extracellular matrix, immune response, embryonic development and angiogenesis. Gene cluster B was enriched in genes involved in synaptic transmission. Gene cluster $C$ was enriched in genes involved in neurogenesis and synaptic transmission. 
lists and clustering methods. The genes were classified into three clusters: one cluster of genes overexpressed in gliomas with EGFR amplification (gene cluster A, 698 genes), one cluster of genes overexpressed in oligodendrogliomas with $1 \mathrm{p} 19 \mathrm{q}$ codeletion (gene cluster C, 488 genes) and a smaller cluster of genes expressed by some samples of both groups (gene cluster B, 180 genes). Enrichment analysis was performed on these three gene clusters. First, chromosome enrichment analysis demonstrated that these gene clusters did not simply reflect the underlying genomic alterations. Indeed, gene cluster A was enriched in genes located on chromosome 4 (53 genes, $\mathrm{p}<10^{-4}$ ) and on chromosome 7 (43 genes, $\mathrm{p}<10^{-}$ ${ }^{2}$ ), but not in genes located on chromosome 1 or chromosome 19. Neither gene cluster $C$ nor gene cluster $B$ was enriched in genes located on chromosome 10. In contrast, the three gene clusters were enriched in genes with specific ontologic classes. Gene cluster A was most significantly enriched in genes involved in: immune response (55 genes, $\mathrm{p}<10^{-4}$ ), extracellular matrix (37 genes, $\mathrm{p}<10^{-4}$ ), proliferation (45 genes, $\mathrm{p}<10^{-4}$ ), blood vessel development $\left(17\right.$ genes, $\left.\mathrm{p}<10^{-4}\right)$ and embryonic development (14 genes, $\left.\mathrm{p}<10^{-4}\right)$. This cluster contained several genes well-known to be overexpressed in glioblastomas (IGFBP2, CHI3L1) and markers of glioblastoma cancer stem cells as well (CD133, IQGAP1). In contrast, gene cluster $\mathrm{C}$ was significantly enriched in genes with different specific ontologic classes: nervous system development (42 genes, $\mathrm{p}<10^{-4}$ ), synaptic transmission $(26$ genes, $\mathrm{p}<$ $10^{-4}$ ) and neurogenesis (13 genes, $\mathrm{p}<10^{-4}$ ). Actually, most of the genes in gene cluster $\mathrm{C}$ were either related to neuronal function or neuronal development or known to be highly expressed in normal brain. Gene cluster B was also enriched in genes involved in synaptic transmission (17 genes, $\mathrm{p}<10^{-4}$ ) and nervous system development (16 genes, $\left.\mathrm{p}<10^{-4}\right)$. However, two ontologic classes specifically found in this cluster (neurofilament ( 3 genes, $\mathrm{p}<10^{-}$ ${ }^{4}$ ) and axon ensheathment ( 2 genes, $\left.\mathrm{p}<10^{-2}\right)$ ) suggested that this cluster contained genes expressed in more differentiated neural cells than gene cluster C.

\section{Oligodendrogliomas with Ip/9q codeletion express specific subsets of neuronal genes}

In order to better characterize the expression of neuronal genes in gliomas with complete $1 \mathrm{p} 19 \mathrm{q}$ codeletion, we performed a new hierarchical clustering analysis with samples of normal brain (GSE7307), including grey matter (cortex) and white matter (corpus callosum). As glioblastomas expressed genes of neural cancer stem cells, we also included samples of glioblastoma cancer stem cells (GSE7181) [7] in this analysis. Still using the most differentially expressed 1366 probe sets, the samples clustered into two major groups: one containing $1 \mathrm{p} 19 \mathrm{q}$ codeleted gliomas, normal white matter and normal grey matter, and the other containing EGFR amplified gliomas and cancer stem cells (Figure 3). Again this clustering was found to be extremely robust and was conserved across different gene lists and clustering methods. Gene ontology enrichment analysis was performed on the main gene clusters (A to J). Despite the clustering of 1p19q codeleted gliomas with normal brain, they showed substantial differences. First, the genes characteristics of the corpus callosum (gene cluster A), enriched in myelination genes (5 genes, $\mathrm{p}<10^{-4}$ ), were not overexpressed in gliomas with $1 \mathrm{p} 19 \mathrm{q}$ codeletion. Second, gliomas with $1 \mathrm{p} 19 \mathrm{q}$ only overexpressed one subset of the neuronal genes characteristic of the cortex samples (gene clusters B and C). For example, among the neurofilament genes (INA, NEFH, NEFM, $N E F L$ ) present in cluster $\mathrm{C}$, alphainternexin (INA) was the only one overexpressed in both gliomas with $1 \mathrm{p} 19 \mathrm{q}$ codeletion and cortex samples in comparison to gliomas with EGFR amplification. Third, 1p19q codeleted gliomas were characterized by one specific cluster (gene cluster D) enriched in genes involved in CNS development ( 6 genes, $\mathrm{p}<10^{-4}$ ), which also contained genes known to be specifically expressed in neuronal cells in the physiological state, e.g. DCX and GALNT1 [21,22]. Thus, gliomas with $1 \mathrm{p} 19 \mathrm{q}$ codeletion had a specific gene expression pattern of neuronal genes different from the samples of normal brain. Gliomas with EGFR amplification and glioblastoma cancer stem cells were both characterized by a large gene cluster $(G)$ most significantly enriched in genes involved in proliferation ( 34 genes, $\mathrm{p}<10^{-4}$ ) and in CNS development (16 genes, $\mathrm{p}<10^{-4}$ ). Gliomas with EGFR amplification segregated from the cancer stem cells by one main gene cluster (I) enriched in genes involved in immune response ( 11 genes, $\left.\mathrm{p}<10^{-4}\right)$, extracellular matrix $\left(7\right.$ genes, $\left.\mathrm{p}<10^{-4}\right)$ and angiogenesis $(4$ genes, $\mathrm{p}<$ $\left.10^{-4}\right)$.

\section{Most characteristic genes associated with oligodendrogliomas with Ip/9q codeletion}

To find the genes most specifically associated with oligodendrogliomas with 1p19q codeletion, we selected the probe sets that were consistently ( $>2$-fold) and significantly ( $\mathrm{t}$ test $\mathrm{p}<0.001$ ) overexpressed in these gliomas when they were independently compared to each of the 4 other samples groups (i.e., gliomas with EGFR amplification, cortex samples, corpus callosum samples and glioblastoma cancer stem cells). Eighty-six probe sets corresponding to 39 well-annotated genes met these criteria (Table 1 and see additional file 1). Several genes on this list are known to be highly expressed in normal brain (CSMD3, C20orf42, CTTNBP2), and one is known to be specifically expressed by neuronal cells (GALNT13) [22]. Two transcription factors that play a role in CNS development were also specifically overexpressed (ATOH8, NFIB). ATOH8 is a basic-helix-loop-helix transcription factor, whose homolog in mouse has been demonstrated to regulate neuronal versus glial fate [23]. NFIB plays a 


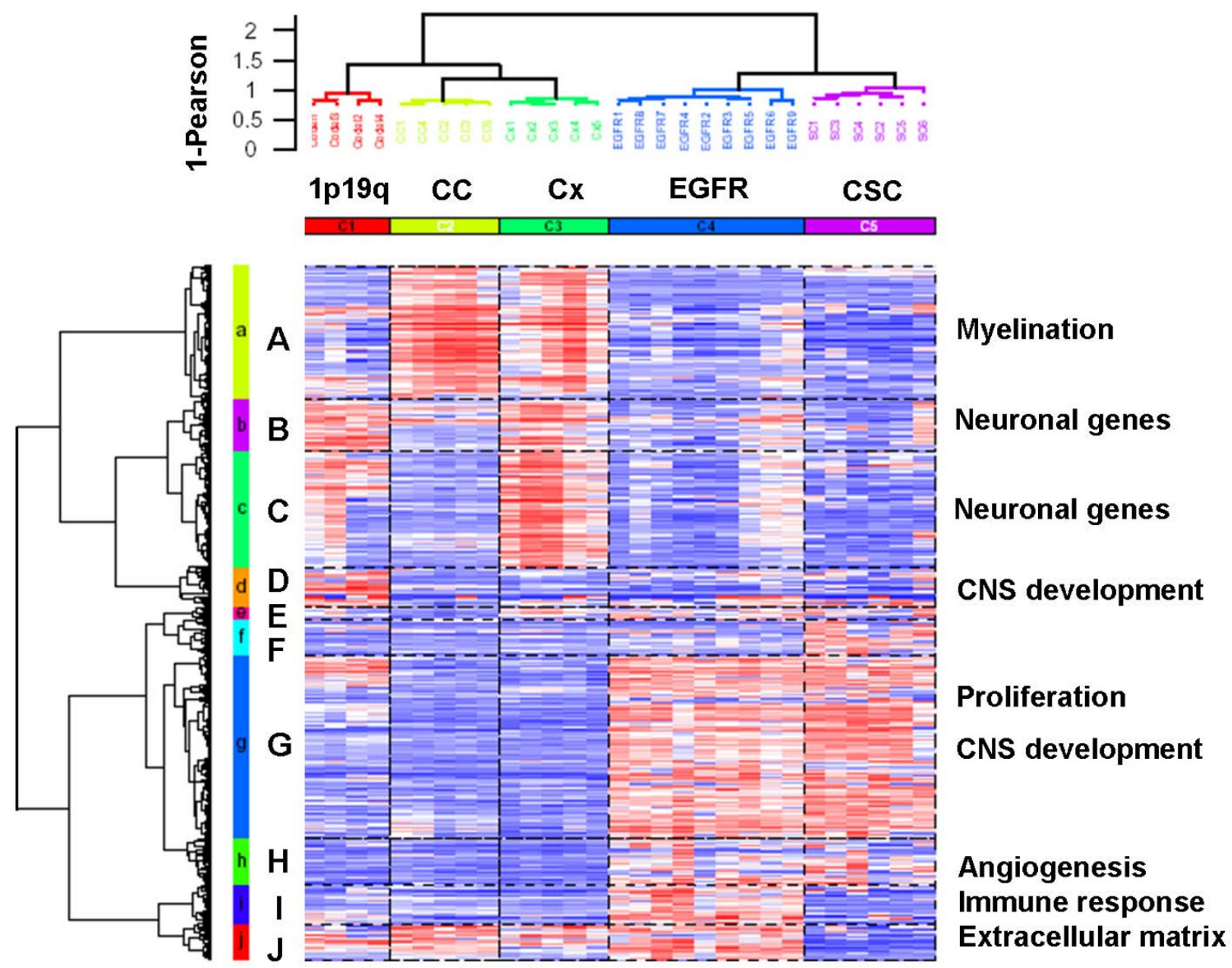

Figure 3

Unsupervised clustering of 4 gliomas with I p I 9 codeletion, 9 gliomas with EGFR amplification, 6 glioblastoma cancer stem cells cell lines and 10 normal brain tissue samples. Unsupervised hierarchical clustering was performed using the 1366 probe sets whose expression varied the most across the 29 samples (probe sets with a robust coefficient of variation superior to the $97.5^{\text {th }}$ percentile). Samples and genes were clustered using Ward's linkage and I-Pearson correlation coefficient. For each probe set, data were median-centered (white), with the lowest and highest intensity values in blue and red, respectively. Ip $\mid 9 q=I p I 9 q$ codeletion, $E G F R=E G F R$ amplification, $C C=$ corpus callosum, Cx $=$ cortex, CSC = cancer stem cells. The 29 gliomas were classified into 2 groups and 5 subgroups. Gliomas with EGFR amplification were classified with the cancer stem cell lines. Gliomas with Ip I9q codeletion were classified with the normal brain samples, however their gene expression pattern was clearly different from the gene expression pattern of the white matter (corpus callosum) and grey matter (cortex) samples.

role in brain development, and $N f i b$ deficient mice exhibit callosal agenesis [24]. Finally, an intriguing feature was the specific overexpression of both BMP2, which promotes astroglial differentiation, and its antagonist NOG, which has been shown to promote both neuronal and oligodendroglial differentiation [25-27].

\section{Oligodendrogliomas with IpI9q have a proneural gene expression profile}

As gliomas with $1 \mathrm{p} 19 \mathrm{q}$ codeletion expressed neuronal genes, we performed gene set enrichment analysis (GSEA) to study the relationship between the gene expression profile of these gliomas and the "proneural" gene expression signatures that have been described in high grade gliomas 
Table I: Most characteristic genes associated with oligodendrogliomas with Ip I 9q codeletion

\begin{tabular}{|c|c|c|c|c|c|c|c|c|}
\hline Probe set & Title & Gene Symbol & $\begin{array}{l}\text { Gene ontology } \\
\text { (biological } \\
\text { process) }\end{array}$ & $\begin{array}{l}\text { High expression } \\
\text { in: }\end{array}$ & FD/EGFR & FD/Cx & FD/CC & FD/Stem cells \\
\hline 206785_s_at & $\begin{array}{l}\text { Killer cell lectin-like } \\
\text { receptor subfamily } \\
\text { C, member I//I } \\
\text { member } 2\end{array}$ & $K L R C I / / K L R C 2$ & $\begin{array}{l}\text { Cellular defense } \\
\text { response }\end{array}$ & Natural killer cells & 104.2 & 92.1 & 61.4 & 66.7 \\
\hline $\begin{array}{l}\text { 243779_at, } \\
\text { 236536_at }\end{array}$ & $\begin{array}{l}\text { UDP-N-acetyl-alpha- } \\
\text { D- } \\
\text { galactosamine:polype } \\
\text { ptide N- } \\
\text { acetylgalactosaminylt } \\
\text { ransferase I3 } \\
\text { (GalNAc-TI3) }\end{array}$ & GALNTI3 & $\begin{array}{l}\text { Protein amino acid } \\
\text { O-linked } \\
\text { glycosylation }\end{array}$ & $\begin{array}{l}\text { Specifically } \\
\text { expressed in } \\
\text { neuronal cells }\end{array}$ & 31.8 & 18.2 & 17.1 & 15.0 \\
\hline $\begin{array}{l}\text { I558706_a_at, } \\
\text { 228890_at }\end{array}$ & $\begin{array}{l}\text { Atonal homolog } 8 \\
\text { (Drosophila) }\end{array}$ & $\underline{A T O H 8}$ & $\begin{array}{l}\text { Regulation of } \\
\text { transcription }\end{array}$ & --- & 26.1 & 30.8 & 21.4 & 27.1 \\
\hline 240228_at & $\begin{array}{l}\text { CUB and Sushi } \\
\text { multiple domains } 3\end{array}$ & CSMD3 & $\begin{array}{l}\text { Integral to } \\
\text { membrane }\end{array}$ & Brain & 22.7 & 11.8 & 13.9 & 15.1 \\
\hline 207723_s_at & $\begin{array}{l}\text { Killer cell lectin-like } \\
\text { receptor subfamily } \\
\text { C, member } 3\end{array}$ & $K L R C 3$ & $\begin{array}{l}\text { Cellular defense } \\
\text { response }\end{array}$ & Natural killer cells & 17.9 & 27.3 & 13.1 & 11.3 \\
\hline 230826_at & $\begin{array}{l}\text { Monocyte to } \\
\text { macrophage } \\
\text { differentiation- } \\
\text { associated } 2\end{array}$ & MMD2 & Cytolysis & --- & 17.2 & 7.2 & 9.1 & 26.2 \\
\hline $\begin{array}{l}\text { 60474_at, } \\
\text { 218796_at }\end{array}$ & $\begin{array}{l}\text { Chromosome } 20 \\
\text { open reading frame } \\
42\end{array}$ & C20orf42 & Cell adhesion & $\begin{array}{l}\text { Brain (among } \\
\text { others) }\end{array}$ & 16.2 & 37.4 & 29.1 & 19.6 \\
\hline 231798_at & Noggin & NOG & $\begin{array}{l}\text { Nervous system } \\
\text { development }\end{array}$ & --- & 11.2 & 9.2 & 9.5 & 13.6 \\
\hline 1556599_s_at & $\begin{array}{l}\text { Cyclic AMP- } \\
\text { regulated } \\
\text { phosphoprotein, } 21 \\
\text { kD }\end{array}$ & ARPP-2I & --- & -- & II.I & 14.0 & 16.8 & 13.9 \\
\hline 227845_s_at & $\begin{array}{l}\text { Src homology } 2 \\
\text { domain containing } \\
\text { transforming protein } \\
\text { D }\end{array}$ & SHD & $\begin{array}{l}\text { Intracellular } \\
\text { signaling cascade }\end{array}$ & --- & 10.3 & 10.6 & 16.5 & 7.6 \\
\hline $\begin{array}{l}\text { 205289_at, } \\
\text { 205290_s_at }\end{array}$ & $\begin{array}{l}\text { Bone morphogenetic } \\
\text { protein } 2\end{array}$ & BMP2 & $\begin{array}{l}\text { Positive regulation } \\
\text { of astrocyte } \\
\text { differentiation }\end{array}$ & $\begin{array}{l}\text { Brain (among } \\
\text { others) }\end{array}$ & 10.1 & 30.7 & 25.9 & 12.7 \\
\hline 205330_at & $\begin{array}{l}\text { Meningioma } \\
\text { (disrupted in } \\
\text { balanced } \\
\text { translocation) I }\end{array}$ & MNI & $\begin{array}{l}\text { Negative regulation } \\
\text { of progression } \\
\text { through cell cycle }\end{array}$ & $\begin{array}{l}\text { Ubiquitously } \\
\text { expressed }\end{array}$ & 8.4 & 5.8 & 9.5 & 15.9 \\
\hline 219668_at & $\begin{array}{l}\text { Ganglioside-induced } \\
\text { differentiation- } \\
\text { associated protein I- } \\
\text { like I }\end{array}$ & GDAPILI & --- & --- & 8.4 & 4.2 & 9.1 & 7.9 \\
\hline 204530_s_at & $\begin{array}{l}\text { Thymus high } \\
\text { mobility group box } \\
\text { protein TOX }\end{array}$ & TOX & $\begin{array}{l}\text { Regulation of } \\
\text { transcription }\end{array}$ & --- & 8.3 & 6.6 & 12.5 & 6.0 \\
\hline $\begin{array}{l}\text { 228790_at, } \\
\text { 221959_at }\end{array}$ & $\begin{array}{l}\text { Chromosome } 8 \\
\text { open reading frame } \\
72\end{array}$ & C8orf72 & --- & --- & 7.6 & 14.6 & 19.1 & 36.6 \\
\hline 232136_s_at & $\begin{array}{l}\text { Cortactin binding } \\
\text { protein } 2\end{array}$ & CTTNBP2 & --- & Brain & 5.4 & 7.1 & 4.3 & 6.5 \\
\hline 233136_at & $\begin{array}{l}\text { Poly }(\mathrm{A}) \text { binding } \\
\text { protein, cytoplasmic } \\
5\end{array}$ & PABPC5 & --- & Fetal brain & 5.4 & 4.6 & 4.6 & 4.9 \\
\hline 219093_at & $\begin{array}{l}\text { Phosphotyrosine } \\
\text { interaction domain } \\
\text { containing I }\end{array}$ & PIDI & --- & $\begin{array}{l}\text { Brain (among } \\
\text { others) }\end{array}$ & 5.1 & 12.3 & 23.0 & 4.0 \\
\hline 205773_at & $\begin{array}{l}\text { Cytoplasmic } \\
\text { polyadenylation } \\
\text { element binding } \\
\text { protein } 3\end{array}$ & СРEBЗ & Nucleotide binding & -- & 4.5 & 4.0 & 4.8 & 5.4 \\
\hline 1560265_at & $\begin{array}{l}\text { Glutamate receptor, } \\
\text { ionotropic, kainate } 2\end{array}$ & GRIK2 & $\begin{array}{l}\text { Regulation of } \\
\text { synaptic } \\
\text { transmission }\end{array}$ & $\begin{array}{l}\text { Cerebellum, } \\
\text { cerebral cortex }\end{array}$ & 4.5 & 3.7 & 5.9 & 7.1 \\
\hline 238526_at & $\begin{array}{l}\text { RAB3A interacting } \\
\text { protein (rabin3) }\end{array}$ & RAB3IP & protein transport & $\begin{array}{l}\text { Brain (among } \\
\text { others) }\end{array}$ & 4.4 & 5.9 & 7.2 & 3.2 \\
\hline $\begin{array}{l}\text { 21300I_at, } \\
\text { 219514_at }\end{array}$ & Angiopoietin-like 2 & ANGPTL2 & Development & $\begin{array}{l}\text { Heart among } \\
\text { others }\end{array}$ & 3.9 & 12.2 & 6.0 & 4.0 \\
\hline 229590_at & $\begin{array}{l}\text { Ribosomal protein } \\
\text { LI3 }\end{array}$ & RPLI3 & Translation & --- & 3.8 & 3.7 & 3.8 & 2.8 \\
\hline 206117_at & $\begin{array}{l}\text { Tropomyosin I } \\
\text { (alpha) }\end{array}$ & TPMI & Cell motility & $\begin{array}{l}\text { Muscle among } \\
\text { others }\end{array}$ & 3.6 & 4.1 & 4.2 & 3.3 \\
\hline $\begin{array}{l}\text { 202315_s_at, } \\
\text { 217223_s_at }\end{array}$ & $\begin{array}{l}\text { Breakpoint cluster } \\
\text { region }\end{array}$ & $B C R$ & $\begin{array}{l}\text { Regulation of Rho } \\
\text { protein signal } \\
\text { transduction }\end{array}$ & --- & 3.3 & 4.4 & 7.6 & 4.5 \\
\hline
\end{tabular}


Table I: Most characteristic genes associated with oligodendrogliomas with Ip I9q codeletion (Continued)

\begin{tabular}{|c|c|c|c|c|c|c|c|c|}
\hline 234268_at & $\begin{array}{l}\text { Solute carrier family } \\
2 \text { (facilitated glucose } \\
\text { transporter), } \\
\text { member } 13\end{array}$ & SLC2AI3 & $\begin{array}{l}\text { Carbohydrate } \\
\text { transport }\end{array}$ & Brain & 3.1 & 3.4 & 4.1 & 3.2 \\
\hline $\begin{array}{l}\text { 228813_at, } \\
\text { 204225_at }\end{array}$ & $\begin{array}{l}\text { Histone deacetylase } \\
4\end{array}$ & HDAC4 & $\begin{array}{l}\text { Nervous system } \\
\text { development }\end{array}$ & $\begin{array}{l}\text { Ubiquitously } \\
\text { expressed }\end{array}$ & 3.1 & 2.6 & 3.9 & 4.4 \\
\hline 2095 II_at & $\begin{array}{l}\text { Polymerase (RNA) II } \\
\text { (DNA directed) } \\
\text { polypeptide F }\end{array}$ & POLR2F & $\begin{array}{l}\text { Regulation of } \\
\text { transcription }\end{array}$ & --- & 3.0 & 6.9 & 4.7 & 3.0 \\
\hline $\begin{array}{l}\text { 213033_s_at, } \\
\text { 213032_at }\end{array}$ & Nuclear factor I/B & NFIB & $\begin{array}{l}\text { Regulation of } \\
\text { transcription, DNA- } \\
\text { dependent, Brain } \\
\text { development }\end{array}$ & -- & 3.0 & 10.7 & 13.8 & 8.2 \\
\hline 204100_at & $\begin{array}{l}\text { Thyroid hormone } \\
\text { receptor, alpha } \\
\text { (erythroblastic } \\
\text { leukemia viral (v-erb- } \\
\text { a) oncogene } \\
\text { homolog, avian) }\end{array}$ & THRA & $\begin{array}{l}\text { Negative regulation } \\
\text { of transcription }\end{array}$ & $\begin{array}{l}\text { Brain (among } \\
\text { others) }\end{array}$ & 2.9 & 2.9 & 2.2 & 3.7 \\
\hline 230198_at & $\begin{array}{l}\text { WD repeat domain } \\
37\end{array}$ & WDR37 & --- & --- & 2.8 & 4.0 & 2.8 & 2.6 \\
\hline 213758_at & $\begin{array}{l}\text { Cytochrome c } \\
\text { oxidase subunit IV } \\
\text { isoform I }\end{array}$ & cox4II & Electron transport & $\begin{array}{l}\text { Ubiquitously } \\
\text { expressed }\end{array}$ & 2.4 & 2.2 & 2.7 & 3.2 \\
\hline 221012_s_at & $\begin{array}{l}\text { Tripartite motif- } \\
\text { containing } 8 / / / \\
\text { tripartite motif- } \\
\text { containing } 8\end{array}$ & TRIM8 & -- & $\begin{array}{l}\text { Brain (among } \\
\text { others) }\end{array}$ & 2.3 & 3.1 & 3.2 & 3.2 \\
\hline 202182_at & $\begin{array}{l}\text { GCN5 general } \\
\text { control of amino- } \\
\text { acid synthesis 5-like } \\
2 \text { (yeast) }\end{array}$ & GCN5L2 & $\begin{array}{l}\text { Regulation of } \\
\text { transcription, DNA- } \\
\text { dependent }\end{array}$ & $\begin{array}{l}\text { Ubiquitously } \\
\text { expressed }\end{array}$ & 2.3 & 2.5 & 2.4 & 2.3 \\
\hline 214198_s_at & $\begin{array}{l}\text { DiGeorge syndrome } \\
\text { critical region gene } 2\end{array}$ & DGCR2 & Cell adhesion & $\begin{array}{l}\text { Brain (among } \\
\text { others) }\end{array}$ & 2.3 & 3.4 & 5.0 & 2.4 \\
\hline 225334_at & $\begin{array}{l}\text { Chromosome } 10 \\
\text { open reading frame } \\
32\end{array}$ & Cl0orf32 & --- & --- & 2.2 & 3.5 & 4.1 & 3.2 \\
\hline 210690_at & $\begin{array}{l}\text { Killer cell lectin-like } \\
\text { receptor subfamily } \\
\text { C, member } 4\end{array}$ & KLRC4 & $\begin{array}{l}\text { Cellular defense } \\
\text { response }\end{array}$ & Natural killer cells & 2.2 & 2.2 & 2.0 & 2.2 \\
\hline 203938_s_at & $\begin{array}{l}\text { TATA box binding } \\
\text { protein (TBP)- } \\
\text { associated factor, } \\
\text { RNA polymerase I, } \\
\text { C, I I0kDa }\end{array}$ & TAFIC & Transcription & -- & 2.1 & 3.2 & 2.6 & 2.1 \\
\hline 217969_at & $\begin{array}{l}\text { Chromosome 1I } \\
\text { open reading frame2 }\end{array}$ & Cllorf2 & -- & -- & 2.0 & 2.8 & 3.9 & 3.3 \\
\hline
\end{tabular}

39 well-characterized genes were significantly upregulated $(F C>2$ and $p<0.00 I)$ in oligodendrogliomas with IpI9q codeletion in comparison to each of the 4 other sample groups. Underlined genes were studied and validated by real-time RT-PCR in the independent sample set. FD/EGFR = Fold difference of geometric means (FD) in gliomas with Ipl9q codeletion in comparison to gliomas with EGFR amplification, FD/Cx $=F D$ in gliomas with Ip I $9 q$ codeletion in comparison to cortex samples, FD/CC = FD in gliomas with Ip $19 q$ codeletion in comparison to corpus callosum, FD/Stem cells $=$ FD in gliomas with IpI9q codeletion in comparison to glioblastomas cancer stem cells [7].

with a good prognosis (Figure 4 ) $[5,14,28]$. This test determines the over-representation of a gene set (list of genes) at the extremes (top or bottom) of the ordered, nonredundant dataset (list of all of the genes being used to compare two groups of samples). This analysis demonstrated that gliomas with $1 \mathrm{p} 19 \mathrm{q}$ codeletion in comparison to gliomas with EGFR amplification were significantly enriched in the "proneural" gene set associated with good prognosis reported by Phillips et al. and in the good prognosis neurogenesis-related gene set reported by Freije et al. (HC1A gene set) $[5,28]$. They were also enriched in the HC1B gene set (neuronal genes) of Freije et al. In contrast, gliomas with EGFR amplification were enriched in gene sets associated with poor prognosis ("proliferation" and "mesenchymal" gene sets of Phillips et al., and HC2A (enriched in proliferation genes) and HC2B (enriched in extracellular matrix genes) gene sets of Freije et al.) $[5,28]$.
Next we used the 35 genes signature developed by Phillips et al. to distinguish the three groups of high grade gliomas (proneural, proliferative and mesenchymal) in order to perform unsupervised hierarchical clustering [5]. As shown in Figure 5, the gliomas with 1p19q codeletion were classified as proneural. Thus, there was a clear association between the "proneural" gene expression profile and $1 \mathrm{p} 19 \mathrm{q}$ codeletion.

\section{Real-time $R T-P C R$ validation}

To validate these findings, we studied the expression of 22 selected genes differentially expressed (11 up and 11 down) between the two groups of gliomas in an independent data set of 16 gliomas ( 8 gliomas with EGFR amplification and 8 gliomas with $1 \mathrm{p} 19 \mathrm{q}$ codeletion). This study was performed in comparison with 3 samples of normal brain obtained from epileptic surgery (Table 2, 



D $\quad E S=0.82, p<0.001$
B $E S=-0.79, p<0.001$ Enrichment plot: PROLIFERATIVE_PHILLIPS

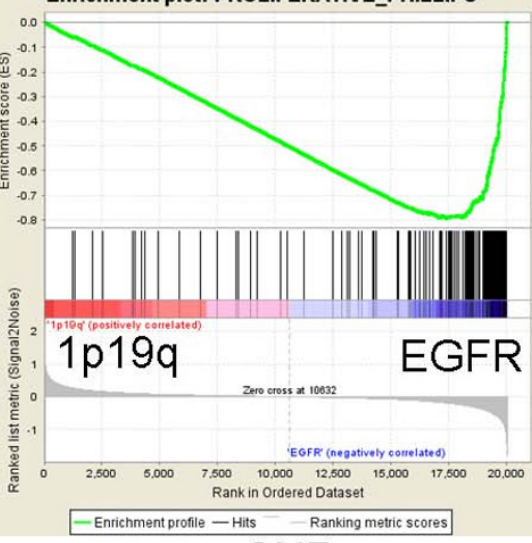

SNR

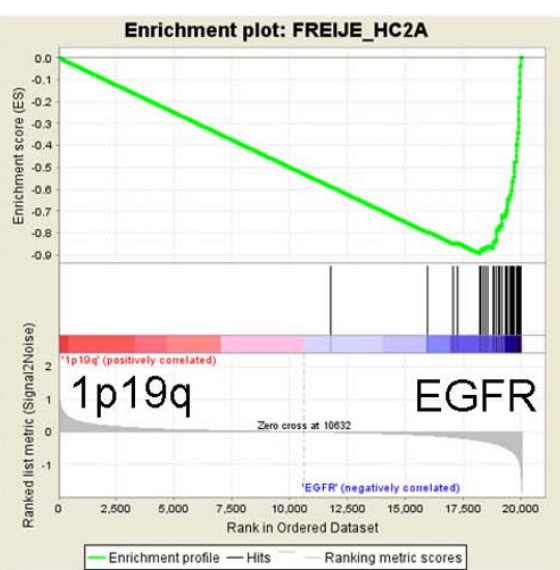

E $E S=-0.89, p<0.001$
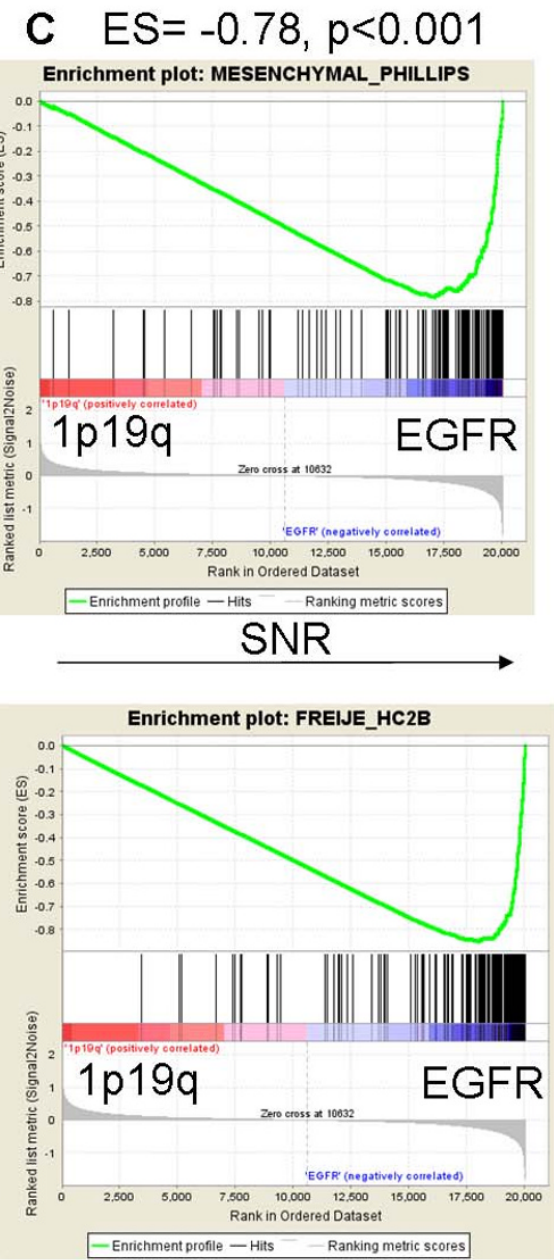

F $\quad E S=-0.85, p<0.001$

Figure 4

GSEA Enrichment Score curves. Gene set enrichment analysis (GSEA) was performed with 6 different gene sets obtained from the studies of Phillips et al. and Freije et al. Phillips' study gene sets: A: Proneural gene set $(n=220$ genes), B: Proliferative gene set $(n=148$ genes), C: Mesenchymal gene set $(n=126$ genes). Freije's study gene sets: $D: H C I A$ neurogenesis related gene set $(n=73)$, E: HC2A proliferation related gene set $(n=66$ genes), F: HC2B extracellular matrix related gene set $(n=239$ genes) $[5,28]$. "Signal-to-Noise" ratio (SNR) statistic was used to rank the genes according to their correlation with either the Ip I9q codeletion phenotype (red) or EGFR amplification phenotype (blue). The graph on the bottom of each panel represents the ranked, ordered, non-redundant list of genes. Genes on the far left (red) correlated the most with IpI9q codeleted samples, and genes on the far right (blue) correlated the most with EGFR amplified samples. On each panel, the vertical black lines indicate the position of each of the genes of the studied gene set in the ordered, non-redundant data set. The green curve corresponds to the ES (enrichment score) curve, which is the running sum of the weighted enrichment score obtained from GSEA software. $A$ and $D$ show that gliomas with $I p / 9 q$ codeletion were significantly enriched in the proneural and neurogenesis related $(\mathrm{HCIA})$ gene sets. $\mathrm{B}, \mathrm{C}, \mathrm{D}$ and $\mathrm{E}$ show that gliomas with EGFR amplification were significantly enriched in the proliferation/HC2A and mesenchymal/HC2B gene sets. 
Figure 6 and see additional file 2). Using a univariate ttest, 21 out of the 22 genes studied were shown to be differentially expressed between the two groups of gliomas with a p-value < 0.05 (only NCAM1 was not validated). This confirmed that gliomas with $1 \mathrm{p} 19 \mathrm{q}$ codeletion overexpressed neuronal/normal brain genes (AKR1C3, C20orf42, CTTNBP2, L1CAM, GALNT13) as well as genes implicated in gliogenesis and neurogenesis (OLIG2, BMP2, NOG, DCX, ATOH8). Except L1CAM and AKR1C3, all of these genes were also overexpressed in comparison to the normal brain samples, including two genes (DCX, GALNT13) known to be exclusively expressed in neuronal cells. BMP2, NOG, C20orf42, GALNT13 and OLIG2
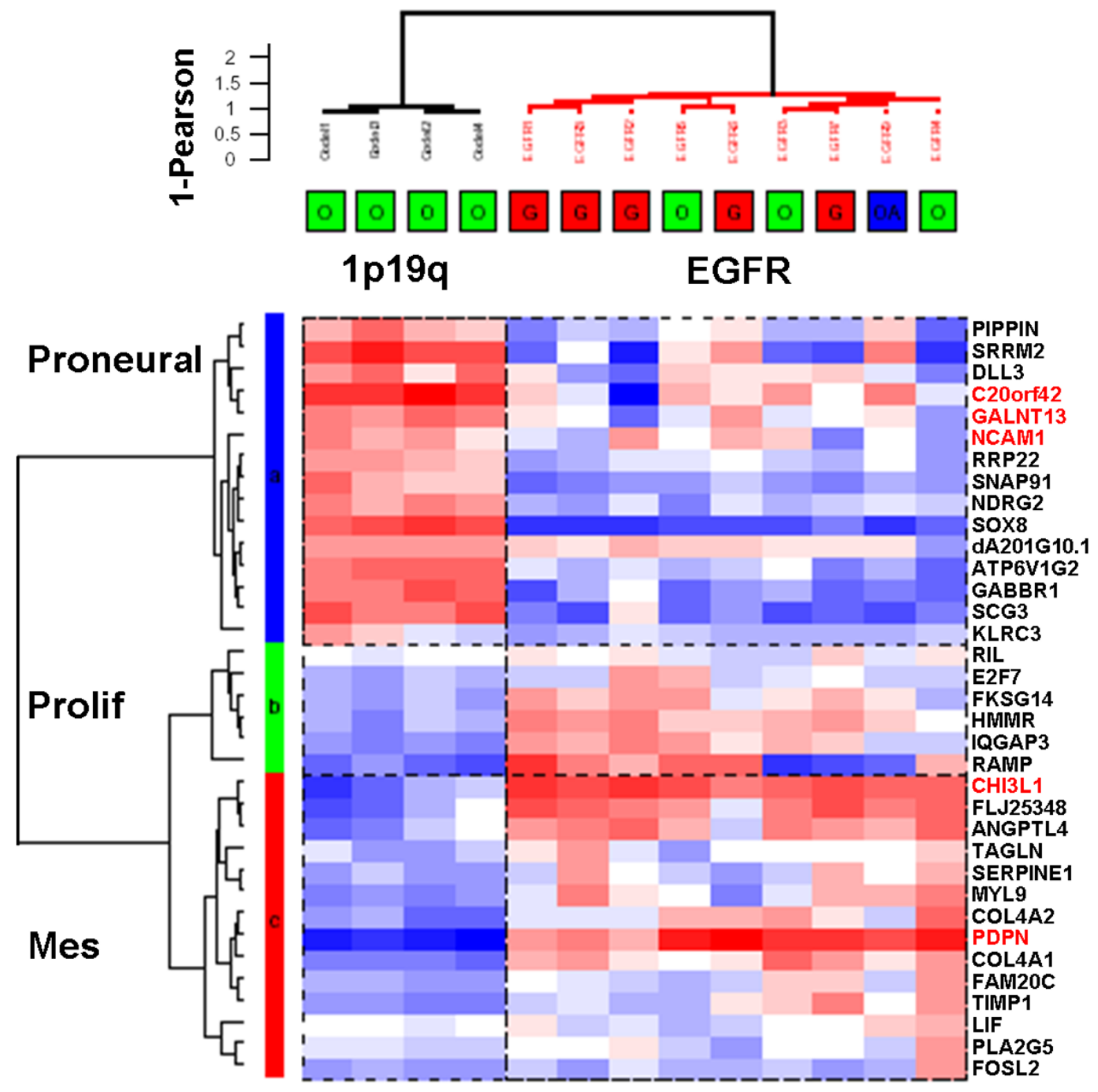

Figure 5

Unsupervised clustering of the 4 gliomas with Ip I9q codeletion and the 9 gliomas with EGFR amplification using 35 genes signature of Phillips et al. [5]. Samples and genes were clustered using Ward's linkage and I-Pearson correlation coefficient. I $\mathrm{p} I 9 q=$ gliomas with $I \mathrm{p} I 9 q$ codeletion, EGFR = gliomas with EGFR amplification. Gliomas with IpI9q codeletion were classified as proneural, whereas gliomas with EGFR amplification had both a mesenchymal and proliferative profile. In red are the genes whose expression was studied in real-time RT-PCR in an independent data set. 
Table 2: Real-time RT-PCR study of 22 differentially expressed genes

\begin{tabular}{|c|c|c|c|c|}
\hline Gene symbol & Description & Gene ontology & $\begin{array}{l}\text { Fold difference of geom } \\
\text { means Ip I } 9 q / E G F R \\
\text { (microarray)* }\end{array}$ & $\begin{array}{l}\text { Fold difference of geom } \\
\text { means Ip I 9q/EGFR in } \\
\text { validation sample set (RT- } \\
\text { PCR)** }\end{array}$ \\
\hline AKRIC3 & $\begin{array}{l}\text { Aldo-keto reductase family I, } \\
\text { member C3 }\end{array}$ & $\begin{array}{l}\text { Prostaglandin } \\
\text { metabolism }\end{array}$ & 17.5 & 7.1 \\
\hline АТОH8 & Atonal homolog 8 (Drosophila) & $\begin{array}{l}\text { Regulation of } \\
\text { transcription }\end{array}$ & 26 & 23.5 \\
\hline BMP2 & Bone morphogenetic protein 2 & $\begin{array}{l}\text { Positive regulation of } \\
\text { astrocyte differentiation }\end{array}$ & 10.1 & 10.2 \\
\hline C20ORF42 & $\begin{array}{l}\text { Chromosome } 20 \text { open reading } \\
\text { frame } 42\end{array}$ & Cell adhesion & 16.2 & 15.7 \\
\hline CTTNBP2 & Cortactin binding protein 2 & --- & 5.4 & 3.9 \\
\hline$D C X$ & $\begin{array}{l}\text { Doublecortex; lissencephaly, X- } \\
\text { linked (doublecortin) }\end{array}$ & CNS development & 5.9 & 6.3 \\
\hline GALNTI 3 & $\begin{array}{l}\text { UDP-N-acetyl-alpha-D- } \\
\text { galactosamine:polypeptide N- } \\
\text { acetylgalactosaminyltransferase } 13 \\
\text { (GalNAc-TI3) }\end{array}$ & $\begin{array}{l}\text { Protein amino acid O- } \\
\text { linked glycosylation }\end{array}$ & 31.7 & 38.4 \\
\hline LICAM & LI cell adhesion molecule & $\begin{array}{l}\text { Nervous system } \\
\text { development }\end{array}$ & 14.6 & 24.5 \\
\hline NCAMI & Neural cell adhesion molecule I & Synaptic transmission & 4.8 & $\mathrm{I} .7(\mathrm{NS})$ \\
\hline NOG & Noggin & $\begin{array}{l}\text { Nervous system } \\
\text { development }\end{array}$ & 11.2 & 18.4 \\
\hline OLIG2 & $\begin{array}{l}\text { Oligodendrocyte lineage } \\
\text { transcription factor } 2\end{array}$ & $\begin{array}{l}\text { Nervous system } \\
\text { development }\end{array}$ & 4.7 & 3.7 \\
\hline CCNBI & Cyclin BI & Mitosis & 0.2 & 0.2 \\
\hline CDK2 & Cyclin-dependent kinase 2 & Mitosis & 0.2 & 0.2 \\
\hline CHI3LI & $\begin{array}{l}\text { Chitinase 3-like I (cartilage } \\
\text { glycoprotein-39) }\end{array}$ & Chitin catabolism & 0.01 & 0.003 \\
\hline EGFR & $\begin{array}{l}\text { Epidermal growth factor receptor } \\
\text { (erythroblastic leukemia viral (v- } \\
\text { erb-b) oncogene homolog, avian) }\end{array}$ & Cell proliferation & 0.1 & 0.2 \\
\hline GBPI & $\begin{array}{l}\text { Guanylate binding protein I, } \\
\text { interferon-inducible, } 67 \mathrm{kDa}\end{array}$ & Immune response & 0.05 & 0.05 \\
\hline IGFBP2 & $\begin{array}{l}\text { Insulin-like growth factor binding } \\
\text { protein } 2,36 \mathrm{kDa}\end{array}$ & $\begin{array}{l}\text { Regulation of cell } \\
\text { growth }\end{array}$ & 0.02 & 0.01 \\
\hline IQGAPI & $\begin{array}{l}\text { IQ motif containing GTPase } \\
\text { activating protein I }\end{array}$ & Signal transduction & 0.11 & 0.1 \\
\hline PDPN & Podoplanin & $\begin{array}{l}\text { Positive regulation of } \\
\text { cell motility }\end{array}$ & 0.02 & 0.008 \\
\hline PLAT & Plasminogen activator, tissue & Proteolysis & 0.07 & 0.06 \\
\hline POSTN & Periostin, osteoblast specific factor & Cell adhesion & 0.01 & 0.01 \\
\hline RNFI35 & Ring finger protein 135 & --- & 0.2 & 0.2 \\
\hline
\end{tabular}

Fold difference of geometrical means in microarray and in real-time RT-PCR of the 22 genes studied in the independent sample set. $*$ All genes were differentially expressed with a $p$-value $<0.001$ except $D C X(p$-value $=0.004)$. $* *$ All genes were differentially expressed with a $p$-value $<0.05$ except when NS (non significant) is specified.

belong to the list of proneural genes reported by Phillips [5].

In the gliomas with EGFR amplification, we confirmed the overexpression of genes implicated in proliferation (CCNB1, CDK2), extracellular matrix remodeling (PLAT, POSTN), immune response (GBP1), cancer stem cell signaling (IQGAP1) as well as several genes known to be highly expressed in glioblastomas (IGFBP2, CHI3L1, PDPN). CCNB1, CDK2 belong to the proliferative gene list, and CHI3L1 and PDPN, to the mesenchymal gene list of Phillips [5].

\section{Alpha-internexin immunohistochemistry}

Finally, to validate the expression of neuronal genes in gliomas with $1 \mathrm{p} 19 \mathrm{q}$ codeletion at the protein level, we studied the expression of the internexin neuronal intermediate filament protein alpha (INA) which was one of the neuronal genes most overexpressed in these gliomas in comparison to gliomas with EGFR amplification ( $F C=15$, p < 0.001 ). INA is a class-IV neuronal intermediate filament 

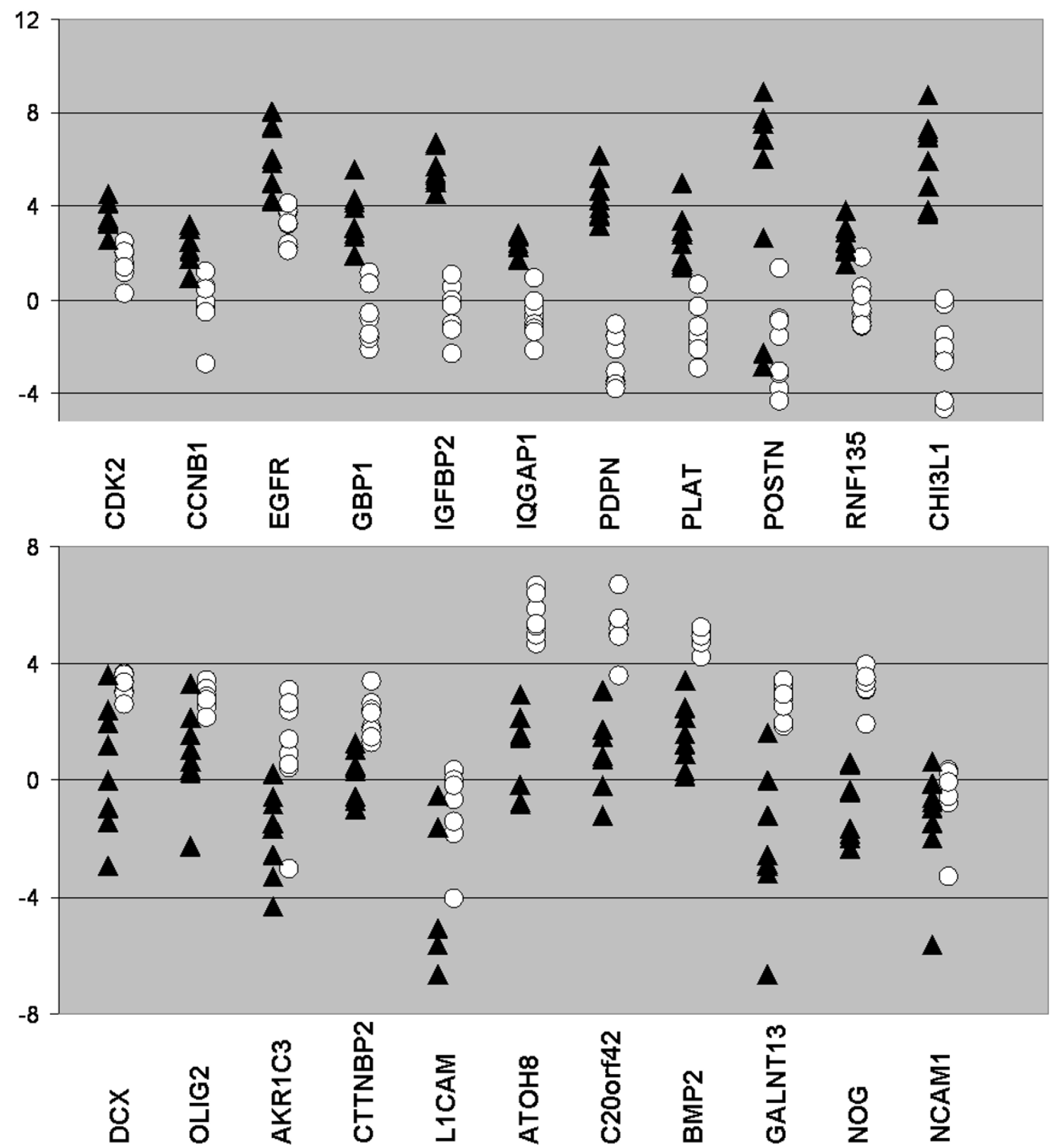

Figure 6

Real-time RT PCR study of 22 genes differentially expressed between Ip I 9q codeleted gliomas and EGFR amplified gliomas. Real-time RT-PCR study of I I genes overexpressed in gliomas with EGFR amplification (top) and II genes overexpressed in gliomas with Ip I9q codeletion (bottom) was performed in an independent data set of 16 gliomas (8 gliomas with EGFR amplification (triangles), 8 gliomas with Ip $19 q$ codeletion (circles)). Each dot represents the relative expression (log2 transformed) of a given gene in one glioma compared with normal brain (median expression in the 3 normal brain samples). Dots above the upper dashed line are upregulated with a fold change larger than 2 in comparison to normal brain; dots below the lower dashed line are downregulated in comparison to normal brain with a fold change larger than 2 . For example, NOG, BMP2 and ATOH8 were overexpressed in all 8 gliomas with Ip $9 \mathrm{q}$ codeletion (circles) in comparison to all 8 gliomas with EGFR amplification (triangles) and in comparison to normal brain. CHI3LI, PLAT, IQGAPI, IGFFBP2 and GBP/were overexpressed in all gliomas with EGFR amplification (triangles) in comparison to gliomas with I $19 \mathrm{q}$ codeletion (circles) and in comparison to normal brain. Except for NCAMI, all 22 genes were differentially expressed $(p<0.05)$. 
involved in the morphogenesis of neurons [29]. Immunostaining for INA was positive in all five oligodendrogliomas with $1 \mathrm{p} 19 \mathrm{q}$ codeletion examined. Immunopositivity was observed in some normal infiltrated neurons but was mostly seen in a specific cytoplasmic perinuclear staining pattern in tumor cells (Figure 7). Between 20 to $50 \%$ of tumor cells displayed this staining, which was different from the staining observed in the infiltrated normal neurons (Figure 7). Among the five glioblastomas with EGFR amplification, immunostaining was negative in four and positive in a scattered pattern in one, in a region displaying some features of oligodendroglial differentiation.

\section{Discussion}

EGFR amplification and whole $1 \mathrm{p} 19 \mathrm{q}$ codeletion are mutually exclusive and predictive of completely different outcomes $[3,4]$. To date, no studies have compared the gene expression profile of these two types of gliomas. Indeed, among microarray studies of gliomas $[5,28,30,31]$, only a few have compared genetically welldefined tumors [32-35]. In addition, these studies were based on LOH or FISH [32-34], and not on CGH-array. Yet, there is a need when interpreting a difference in gene expression to analyze it in relation to the genomic profile. Our data reveals clearly distinct gene expression profiles in these 2 groups of gliomas: those with EGFR amplification express the proliferative and mesenchymal gene set defined by Phillips et al., while 1p19q codeleted gliomas express the proneural group [5]. Moreover, gliomas with EGFR amplification clustered close to tumor stem cells. Indeed, the EGFR pathway is involved in the proliferation of normal neural stem cells and cancer stem cells [36]. This result is consistent with the fact that several studies

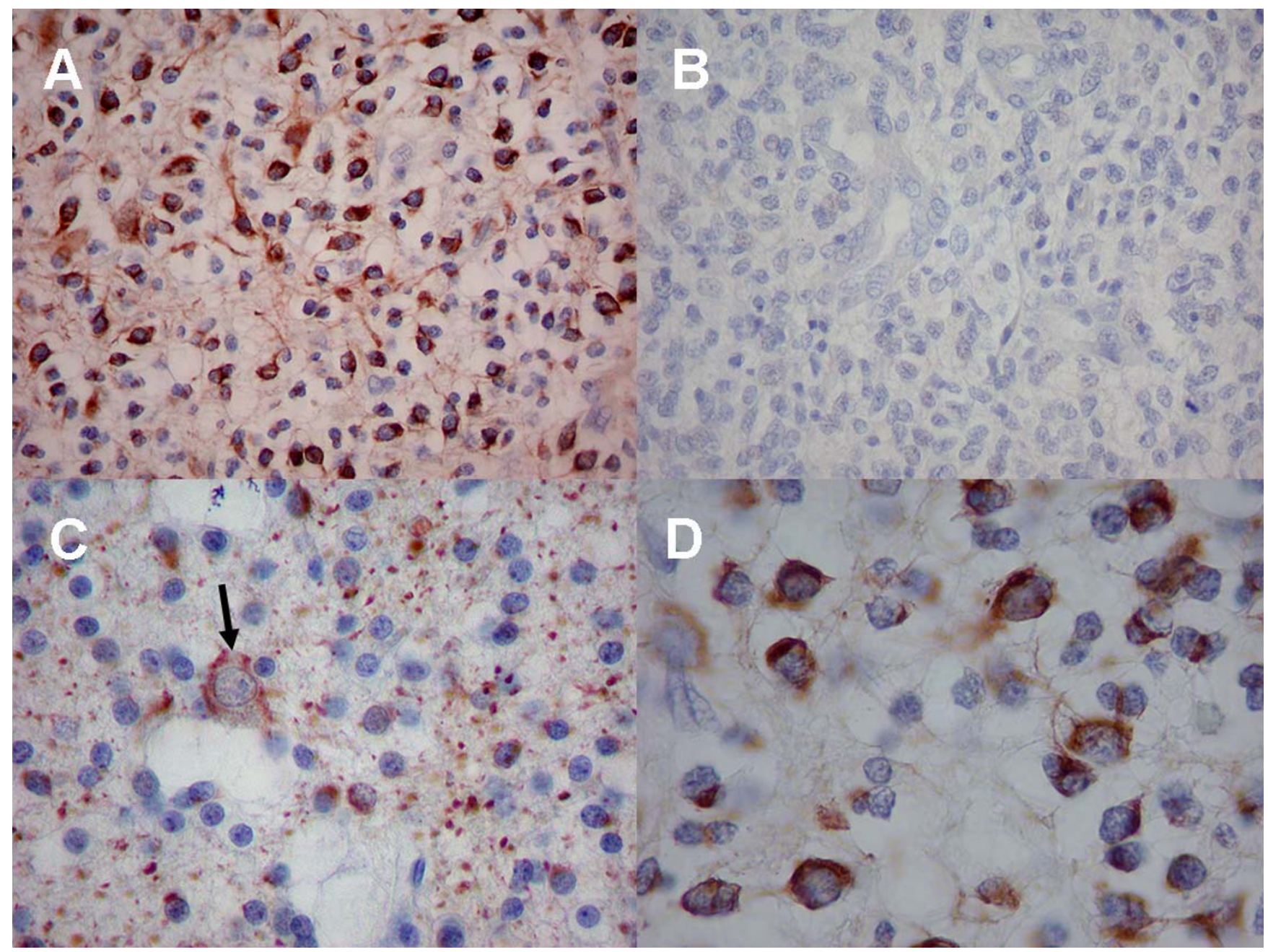

Figure 7

INA immunohistochemistry in Ip I 9q codeleted and EGFR amplified gliomas. Representative alpha-internexin (INA) immunohistostaining in oligodendrogliomas with Ip I9q codeletion (A, C, D) and in glioblastomas with EGFR amplification (B). C: the arrow shows immunopositivity in an entrapped neuron surrounded by immunopositive tumor cells. 
isolated stem like tumor cells from glioblastoma but not from oligodendroglioma. Such studies did not include genetic profiles of the tumors, but data from our group suggest indeed that the capacity of cell renewal (as reflected by the formation of spheroids derived from the tumor) in vitro is tightly correlated with the presence of EGFR amplification (unpublished results). EGFR activation upregulates genes involved in neural stem cell proliferation: one of these genes is ASPM (abnormal spindlelike microcephaly associated) that promotes neuroblast proliferation and symmetric division and is strongly upregulated in glioblastomas. Inhibition of ASPM inhibits glioblastoma cell growth and neural stem cell proliferation [37].

A proneural/normal brain gene expression profile is a factor related to good prognosis and correlates with younger age and grade III histology, with most anaplastic oligodendrogliomas being classified as proneural $[5,28]$. As shown here, this gene expression profile can be determined by a simple, highly discriminating RT-PCR test, and this may be useful for clinical practice. Until now, a proneural gene expression profile has not been reported to be associated with 1p19q codeletion. In Freije's study the number of gliomas with $1 \mathrm{p} 19 \mathrm{q}$ codeletion was too small (4 out 74 patients) to address this question [28]. In Phillips' study the genomic/transcriptomic correlation was limited to patients with astrocytoma histology, and this may have limited the possibility of finding an association between $1 \mathrm{p} 19 \mathrm{q}$ codeletion and the proneural gene expression profile [5]. However, the authors noticed a negative correlation between the proneural gene expression profile and EGFR amplification, similar to the negative correlation between $1 \mathrm{p} 19 \mathrm{q}$ codeletion and EGFR amplification $[3,5]$. Our study demonstrates that there is a strong correlation between $1 \mathrm{p} 19 \mathrm{q}$ codeletion and the expression of proneural genes, suggesting that gliomas with a $1 \mathrm{p} 19 \mathrm{q}$ codeletion represent a subgroup of proneural gliomas. In addition, the expression of neuronal genes in $1 \mathrm{p} 19 \mathrm{q}$ codeleted tumors is consistent with a previous study showing selective expression of neuronal genes in oligodendrogliomas with $1 p$ loss [33]. Whether there is a link between the good prognosis of proneural gliomas and the fact that gliomas with $1 \mathrm{p} 19 \mathrm{q}$ codeletion display a proneural gene expression profile remains to be elucidated. We make the hypothesis that gliomas without $1 \mathrm{p} 19 \mathrm{q}$ codeletion but with a gene expression profile similar to the $1 \mathrm{p} 19 \mathrm{q}$ codeleted gliomas might also harbor a better prognosis.

The expression of "neuronal genes" in 1p19q codeleted gliomas can be interpreted in different ways. As advocated by some authors, this expression is probably due in part to the presence of infiltrated neurons in the tumor [30]. Indeed, $1 \mathrm{p} 19 \mathrm{q}$ codeletion has been suggested to be more frequent in tumors with indistinct, irregular borders, which therefore, are more likely to be contaminated with normal brain tissue [38]. However, as shown here, this normal brain infiltration cannot completely explain the expression of neuronal genes by $1 \mathrm{p} 19 \mathrm{q}$ codeleted gliomas. Indeed, these tumors only express a specific subset of neuronal genes (Figure 3 ). In addition, if the expression of neuronal genes was only due to infiltration of normal brain tissue, the expression pattern of the neuronal genes in these tumors would be similar to their expression in the normal brain samples, which was not the case. Furthermore, we have demonstrated that alpha-internexin (INA), a neuronal protein, was specifically expressed by $1 \mathrm{p} 19 \mathrm{q}$ codeleted glioma tumor cells. Thus INA expression might be used as a simple surrogate marker of $1 \mathrm{p} 19 \mathrm{q}$ codeletion. This hypothesis is currently being tested in a larger series of gliomas. Interestingly, recent ultrastructural analysis of oligodendrogliomas has shown neuronal structures such as synapses and neurosecretory granules [39]. Thus, another hypothesis for the expression of neuronal genes in $1 \mathrm{p} 19 \mathrm{q}$ codeleted glioma tumor cells is that the cell of origin of these tumors could be a progenitor cell giving rise to both neurons and oligodendrocytes $[40,41]$. This progenitor has less capacity of self renewal than the more multipotent neural stem cells. This is consistent with the fact that $1 \mathrm{p} 19 \mathrm{q}$ codeleted oligodendroglioma fails in our hands to form spheroids in vitro (unpublished data). In this setting it is interesting to note that concomitant overexpression of both BMPs and BMP antagonists, such as the concomitant overexpression of BMP2 and NOG observed in $1 \mathrm{p} 19 \mathrm{q}$ codeleted gliomas in our study, has been demonstrated in white matter progenitor cells, which can give rise to both oligodendrocytes and neurons [42]. Another non-exclusive explanation for the expression of "neuronal" genes in oligodendrogliomas could rely on the fact that some genes involved in neurogenesis and classified as "neuronal" may also play a role in oligodendroglial development, e.g. ASCL1/MASH1. This proneural gene specifies a population of telencephalic oligodendrocytes [43] and is also required for oligodendrocyte development in the spinal cord [44]. On the other hand, Olig2 -implicated in oligodendroglial specificationis also involved in neurogenesis: during development, Olig2+ progenitors give rise to both motoneurons and oligodendrocytes in the ventral spinal cord, [45]. Consistently with our results, these data, illustrating the tight connection that exists between neurons and oligodendrocytes fates, bring a new light on the pathogenesis of oligodendrogliomas with $1 \mathrm{p} 19 \mathrm{q}$ codeletion. Finally it is important to remember that current WHO classification is only based on morphological similarity between normal cells and tumor cells, and the link between oligodendrocytes and oligodendrogliomas has never been demonstrated. 


\section{Competing interests}

The authors declare that they have no competing interests.

\section{Authors' contributions}

FD performed the major part of experiments and analysis. FD and MS drafted the manuscript. AI performed the CGH-array study and analysis. AR and SL provided the bioinformatic tools and participated to the analysis. IB and MV performed the real-time RT-PCR validation. YM, SP, JT and KM selected the samples, helped extracting the RNA and performed the immunohistochemistry validation. KHX, OD and JYD assisted with design of the study and with critical examination of the manuscript. MS conceived of and designed the study, participated in its experimental design and interpretation of results, and helped edit the manuscript. All authors read and approved the final manuscript.

\section{Additional material}

\section{Additional file 1}

Complete list of genes differentially expressed $(t$-test, $p<0.001)$ between $1 p 19 q$ codeleted oligodendrogliomas $(n=4)$ and 1$)$ gliomas with EGFR amplification $(n=9), 2)$ cerebral cortex samples $(n=5), 3)$ corpus callosum samples $(n=5) 4)$ Beier's et al. gliomas cancer stem cells $(n=6)$ [7].

Click here for file

[http://www.biomedcentral.com/content/supplementary/14764598-7-41-S1.xls]

\section{Additional file 2}

Detailed results of the 22 genes studied by real-time RT-PCR in the independent sample set of 8 oligodendrogliomas with $1 p 19 q$ codeletion and 8 gliomas with EGFR amplification.

Click here for file

[http://www.biomedcentral.com/content/supplementary/14764598-7-41-S2.xls]

\section{Acknowledgements}

This study was supported by a grant of the Institut National du Cancer (INCA, PL032) and by the Ligue Nationale contre le Cancer.

\section{References}

I. Idbaih A, Marie Y, Pierron G, Brennetot C, Hoang-Xuan K, Kujas M, Mokhtari K, Sanson M, Lejeune J, Aurias A, Delattre O, Delattre JY: Two types of chromosome Ip losses with opposite significance in gliomas. Ann Neurol 2005, 58(3):483-487.

2. Jenkins RB, Blair H, Ballman KV, Giannini C, Arusell RM, Law M, Flynn $H$, Passe S, Felten S, Brown PD, Shaw EG, Buckner JC: A $t(I ; I 9)(q I 0 ; p \mid 0)$ mediates the combined deletions of Ip and $19 q$ and predicts a better prognosis of patients with oligodendroglioma. Cancer Res 2006, 66(20):9852-986I.

3. Idbaih A, Marie Y, Lucchesi C, Pierron G, Manie E, Raynal V, Mosseri V, Hoang-Xuan K, Kujas M, Brito I, Mokhtari K, Sanson M, Barillot E, Aurias A, Delattre JY, Delattre O: BAC array CGH distinguishes mutually exclusive alterations that define clinicogenetic subtypes of gliomas. Int J Cancer 2008, I 22(8): | 778-1786.

4. Dehais C, Laigle-Donadey F, Marie Y, Kujas M, Lejeune J, BenouaichAmiel A, Pedretti M, Polivka M, Xuan KH, Thillet J, Delattre JY, Sanson M: Prognostic stratification of patients with anaplastic gli- omas according to genetic profile. Cancer 2006, 107(8): 1891 - 1897.

5. Phillips HS, Kharbanda S, Chen R, Forrest WF, Soriano RH, Wu TD, Misra A, Nigro JM, Colman H, Soroceanu L, Williams PM, Modrusan Z, Feuerstein BG, Aldape K: Molecular subclasses of high-grade glioma predict prognosis, delineate a pattern of disease progression, and resemble stages in neurogenesis. Cancer Cell 2006, 9(3): 157-173.

6. Gene Expression Omnibus repository (GSE7307) (http:// www.ncbi.nlm.nih.gov/geo).

7. Beier D, Hau P, Proescholdt M, Lohmeier A, Wischhusen J, Oefner PJ, Aigner L, Brawanski A, Bogdahn U, Beier CP: CDI33(+) and CDI33(-) glioblastoma-derived cancer stem cells show differential growth characteristics and molecular profiles. Cancer Res 2007, 67(9):4010-40I5.

8. ArrayExpress: http://www.ebi.ac.uk/arrayexpress.

9. Bioconductor: version 2.0, http://www.bioconductor.org.

10. Irizarry RA, Bolstad BM, Collin F, Cope LM, Hobbs B, Speed TP: Summaries of Affymetrix GeneChip probe level data. Nucleic Acids Res 2003, 3 I(4): el5.

II. Boyault S, Rickman DS, de Reynies A, Balabaud C, Rebouissou S, Jeannot E, Herault A, Saric J, Belghiti J, Franco D, Bioulac-Sage P, LaurentPuig P, Zucman-Rossi J: Transcriptome classification of HCC is related to gene alterations and to new therapeutic targets. Hepatology 2007, 45(I):42-52.

12. Simon R, Peng-Lam A: BRB Array Tools (version 3.5.0), http:// linus.nci.nih.gov/BRB-ArrayTools.html.

13. GSEA: v2.0 software. http://www.broad.mit.edu/gsea.

14. Subramanian A, Tamayo P, Mootha VK, Mukherjee S, Ebert BL, Gillette MA, Paulovich A, Pomeroy SL, Golub TR, Lander ES, Mesirov JP: Gene set enrichment analysis: a knowledge-based approach for interpreting genome-wide expression profiles. Proc Natl Acad Sci U S A 2005, 102(43): I5545- 15550.

15. Affymetrix: annotation file HG-UI33_Plus_2.annot.csv. http:// www.affymetrix.com. 2007.

16. TheGeneOntology: http://www.geneontology.org . 2007.

17. GOA: Gene Ontology Database. ftp://ftp.ebi.ac.uk/pub/databases/GO/goa .

18. DAVID: National Institute of Allergy and Infectious Diseases (NIAID), NIH. http://david.abcc.ncifcrf.gov/. 2008.

19. Bieche I, Parfait B, Le Doussal V, Olivi M, Rio MC, Lidereau R, Vidaud $M$ : Identification of CGA as a novel estrogen receptorresponsive gene in breast cancer: an outstanding candidate marker to predict the response to endocrine therapy. Cancer Res 200I, 6 I (4): I652-I658.

20. Novocastra: http://www.leica-microsystems.com/ Histology_Systems, product code : NCL-A-INTER, clone 2E3.

21. Couillard-Despres S, Winner B, Schaubeck S, Aigner R, Vroemen M, Weidner N, Bogdahn U, Winkler J, Kuhn HG, Aigner L: Doublecortin expression levels in adult brain reflect neurogenesis. Eur J Neurosci 2005, 2 I (I): I- I4.

22. Zhang Y, Iwasaki H, Wang H, Kudo T, Kalka TB, Hennet T, Kubota T, Cheng L, Inaba N, Gotoh M, Togayachi A, Guo J, Hisatomi H, Nakajima K, Nishihara S, Nakamura M, Marth JD, Narimatsu H: Cloning and characterization of a new human UDP-N-acetyl-alphaD-galactosamine:polypeptide $\mathbf{N}$-acetylgalactosaminyltransferase, designated Pp-GalNAc-TI3, that is specifically expressed in neurons and synthesizes GalNAc alpha-serine/ threonine antigen. J Biol Chem 2003, 278(I):573-584.

23. Inoue C, Bae SK, Takatsuka K, Inoue T, Bessho Y, Kageyama R: Math6, a bHLH gene expressed in the developing nervous system, regulates neuronal versus glial differentiation. Genes Cells 200I, 6(II):977-986.

24. Steele-Perkins G, Plachez C, Butz KG, Yang G, Bachurski C], Kinsman SL, Litwack ED, Richards LJ, Gronostajski RM: The transcription factor gene Nfib is essential for both lung maturation and brain development. Mol Cell Biol 2005, 25(2):685-698.

25. Kasai $M$, Satoh $K$, Akiyama $T$ : Wnt signaling regulates the sequential onset of neurogenesis and gliogenesis via induction of BMPs. Genes Cells 2005, 10(8):777-783.

26. Lim DA, Tramontin AD, Trevejo JM, Herrera DG, Garcia-Verdugo JM, Alvarez-Buylla A: Noggin antagonizes BMP signaling to create a niche for adult neurogenesis. Neuron 2000, 28(3):7। 3-726.

27. Mabie PC, Mehler MF, Marmur R, Papavasiliou A, Song Q, Kessler JA: Bone morphogenetic proteins induce astroglial differentia- 
tion of oligodendroglial-astroglial progenitor cells. J Neurosci 1997, I 7(I I):4II2-4I20.

28. Freije WA, Castro-Vargas FE, Fang Z, Horvath S, Cloughesy T, Liau LM, Mischel PS, Nelson SF: Gene expression profiling of gliomas strongly predicts survival. Cancer Res 2004, 64(18):6503-65I0.

29. Chan SO, Chiu FC: Cloning and developmental expression of human 66 kd neurofilament protein. Brain Res Mol Brain Res 1995, 29(I): 177-184.

30. Liang Y, Diehn M, Watson N, Bollen AW, Aldape KD, Nicholas MK, Lamborn KR, Berger MS, Botstein D, Brown PO, Israel MA: Gene expression profiling reveals molecularly and clinically distinct subtypes of glioblastoma multiforme. Proc Natl Acad Sci U S A 2005, 102(16):5814-5819.

31. Nutt CL, Mani DR, Betensky RA, Tamayo P, Cairncross JG, Ladd C, Pohl U, Hartmann C, McLaughlin ME, Batchelor TT, Black PM, von Deimling A, Pomeroy SL, Golub TR, Louis DN: Gene expressionbased classification of malignant gliomas correlates better with survival than histological classification. Cancer Res 2003, 63(7): $1602-1607$.

32. French PJ, Swagemakers SM, Nagel JH, Kouwenhoven MC, Brouwer E, van der Spek P, Luider TM, Kros JM, van den Bent MJ, Sillevis Smitt PA: Gene expression profiles associated with treatment response in oligodendrogliomas. Cancer Res 2005, 65(24): I I335-II344.

33. Mukasa A, Ueki K, Ge X, Ishikawa S, Ide T, Fujimaki T, Nishikawa R, Asai A, Kirino T, Aburatani H: Selective expression of a subset of neuronal genes in oligodendroglioma with chromosome Ip loss. Brain Pathol 2004, I 4(I):34-42.

34. Mukasa A, Ueki K, Matsumoto S, Tsutsumi S, Nishikawa R, Fujimaki $T$, Asai $A$, Kirino $T$, Aburatani $H$ : Distinction in gene expression profiles of oligodendrogliomas with and without allelic loss of Ip. Oncogene 2002, 2I(25):396|-3968.

35. Tews B, Felsberg J, Hartmann C, Kunitz A, Hahn M, Toedt G, Neben K, Hummerich L, von Deimling A, Reifenberger G, Lichter P: Identification of novel oligodendroglioma-associated candidate tumor suppressor genes in $1 \mathrm{p} 36$ and $19 \mathrm{q} / 3$ using microarray-based expression profiling. Int J Cancer 2006, I I9(4):792-800.

36. Lee J, Kotliarova S, Kotliarov Y, Li A, Su Q, Donin NM, Pastorino S, Purow BW, Christopher N, Zhang W, Park JK, Fine HA: Tumor stem cells derived from glioblastomas cultured in bFGF and EGF more closely mirror the phenotype and genotype of primary tumors than do serum-cultured cell lines. Cancer Cell 2006, 9(5):391-403.

37. Horvath S, Zhang B, Carlson M, Lu KV, Zhu S, Felciano RM, Laurance MF, Zhao W, Qi S, Chen Z, Lee Y, Scheck AC, Liau LM, Wu H, Geschwind DH, Febbo PG, Kornblum HI, Cloughesy TF, Nelson SF, Mischel PS: Analysis of oncogenic signaling networks in glioblastoma identifies ASPM as a molecular target. Proc Natl Acad Sci U S A 2006, 103(46): $17402-17407$.

38. Jenkinson MD, du Plessis DG, Smith TS, Joyce KA, Warnke PC Walker C: Histological growth patterns and genotype in oligodendroglial tumours: correlation with MRI features. Brain 2006, I29: I884-|89|.

39. Vyberg M, Ulhøi BP, Teglbjaerg PS: Neuronal features of oligodendrogliomas-an ultrastructural and immunohistochemical study. Histopathology 2007, 50:887-896.

40. Menn B, Garcia-Verdugo JM, Yaschine C, Gonzalez-Perez O, Rowitch $D$, Alvarez-Buylla $A$ : Origin of oligodendrocytes in the subventricular zone of the adult brain. J Neurosci 2006, 26(30):7907-79|8.

4I. Nunes MC, Roy NS, Keyoung HM, Goodman RR, McKhann G 2nd, Jiang L, Kang J, Nedergaard M, Goldman SA: Identification and isolation of multipotential neural progenitor cells from the subcortical white matter of the adult human brain. Nat Med 2003, 9(4):439-447.

42. Sim FJ, Lang JK, Waldau B, Roy NS, Schwartz TE, Pilcher WH, Chandross KJ, Natesan S, Merrill JE, Goldman SA: Complementary patterns of gene expression by human oligodendrocyte progenitors and their environment predict determinants of progenitor maintenance and differentiation. Ann Neurol 2006, 56(I):773-9.

43. Parras CM, Hunt C, Sugimori M, Nakafuku M, Rowitch D, Guillemot F: The proneural gene Mash I specifies an early population of telencephalic oligodendrocytes. I Neurosci 2007, 27(16):4233-4242.
44. Sugimori M, Nagao M, Parras CM, Nakatani H, Lebel M, Guillemot F, Nakafuku M: Ascll is required for oligodendrocyte development in the spinal cord. Development 2008, 135(7): I27|-I28I.

45. Lu QR, Sun T, Zhu Z, Ma N, Garcia M, Stiles CD, Rowitch DH: Common developmental requirement for Olig function indicates a motor neuron/oligodendrocyte connection. Cell 2002, 109(I):75-86.
Publish with Bio Med Central and every scientist can read your work free of charge

"BioMed Central will be the most significant development for disseminating the results of biomedical research in our lifetime. "

Sir Paul Nurse, Cancer Research UK

Your research papers will be:

- available free of charge to the entire biomedical community

- peer reviewed and published immediately upon acceptance

- cited in PubMed and archived on PubMed Central

- yours - you keep the copyright

Submit your manuscript here:

http://www.biomedcentral.com/info/publishing_adv.asp
BiolMedcentral 